\title{
The Transport of Oversized Cargoes from the Perspective of Sustainable Transport Infrastructure in Cities
}

\author{
Jan Petru (D) and Vladislav Krivda *(D) \\ Department of Transport Constructions, Faculty of Civil Engineering, VSB-Technical University of Ostrava, \\ 70800 Ostrava, Czech Republic; jan.petru@vsb.cz \\ * Correspondence: vladislav.krivda@vsb.cz
}

Citation: Petru, J.; Krivda, V. The Transport of Oversized Cargoes from the Perspective of Sustainable Transport Infrastructure in Cities. Sustainability 2021, 13, 5524. https:// doi.org/10.3390/su13105524

Academic Editor: Shailesh Chandra

Received: 28 February 2021

Accepted: 13 May 2021

Published: 15 May 2021

Publisher's Note: MDPI stays neutral with regard to jurisdictional claims in published maps and institutional affiliations.

Copyright: (c) 2021 by the authors. Licensee MDPI, Basel, Switzerland. This article is an open access article distributed under the terms and conditions of the Creative Commons Attribution (CC BY) license (https:// creativecommons.org/licenses/by/ $4.0 /)$.

\begin{abstract}
The article deals with the transport of oversized cargoes from the perspective of parameters of road network in city environments. In recent years, there has been an increase in the transport of products with dimensions and weight considered above standard. It is very difficult to transport these products not only within Europe but also worldwide. This is also pointed out in the European directive, which recommends that all EU member states build a pan-European network of corridors for the transport of oversized cargoes. The article analyses the issue of transport within the transport infrastructure in cities from the perspective of sustainability of road networks for ensuring the passage of oversized cargoes. The article describes the results of research that was performed for the determination of parameters to ensure the passage of oversized cargoes on roads. The article also deals with the analysis of implemented transports, the results of video analysis of monitored transports, measurement of swept paths of vehicles using GPS apparatus and drones, modelling of oversized vehicles in programs for verification of the swept paths of vehicles, simulation of passage of oversized cargo, the determination of values of radii of corners, widths and heights for the transport of cargoes and the distance from solid obstacles. The precondition for the above-mentioned outputs is the practical use of results in planning the transport infrastructure on the entire communication network and the possibility of its application for designing activities associated with the construction or reconstruction of intersections on routes of frequent transport of excessive and oversized cargoes and verification of critical points on the route. The outputs of the work serve as a basis for the processing of technical conditions, which include procedures and technical recommendations within the design practice in the Czech Republic but also abroad. Emphasis is placed on sustainable, safe and economic transport infrastructure.
\end{abstract}

Keywords: oversize cargo; swept path; transport; infrastructure; roundabouts; intersection; sustainability; urban; route

\section{Introduction}

In many European countries, industry, iron and engineering production and the subsequent transport of excessive cargoes have a long history. Traditionally, ironworks and machine plants manufacture custom products of above-standard dimensions and weights, the transport of which is provided within the country and to foreign customers or large ports by special vehicles on chosen routes on roads [1], by rail [2], on water [3,4] or by plane $[5,6]$.

Due to the stated clearance gauges and radii of track alignments, it is very difficult in many European countries to use rail transport. The direction of heavy and excessive cargoes transported by rail, the methodology of criteria and the evaluation of segments of individual transport processes is described in more detail in [2]. We also have the option to use water transport. For example, in [3], the importance of the use of water transport on the river Danube is described. At present, the use of water transport in our conditions is quite problematic. These are mainly the navigability of watercourses and the extent of the 
water network. In recent years, navigability has been highly affected by drought [7-10]. For example, the navigability of the Elbe for the transport of excessive cargoes from the port of Melnik (Czech Republic) to the port of Hamburg (Germany) was only 5 days throughout the whole year 2020. Last but not least, there is the possibility of using air transport. This transport also has its limitations, especially in terms of the weight of the transported cargo, its dimensions and especially the price of transport. Recently, the possibility of transport by airship has also been mentioned [5-7]. Transport by airship is still in its beginning stages and is no more addressed in this article. Therefore, it is necessary to transport these products primarily on selected routes on roads using special vehicles. As a part of the transport of excessive and oversized cargoes, we will focus on the transport of cargoes on roads, the impact of this transport on the communication network, its parameters in terms of safety, long-term sustainability and modifications of roads in cities.

On the example of research [11], which was conducted by the authors of the article in the Czech Republic, we will present the issue of transport of excessive and oversized cargoes and possible modifications of the communication network to ensure their passage. In the Czech Republic, there historically existed routes for the transport of excessive and oversized cargoes [11,12]; the routes were protected by the Ministry of Transport in terms of dimensional and mass permeability. However, after 1992, the Ministry of Transport stopped protecting these chosen routes, even though the Ministry allows 15 to 20 thousand oversized transports a year. Of this number, approximately 5000 shipments per year have above-standard spatial requirements for ensuring their passage. Specialized companies implementing excessive transports spend more and more time and resources to ensure technical adjustments of the spatial arrangement of roads for the passage of individual oversized cargoes. An example of an issue is the transport of oversized cargo, which went from the Czech Republic to the port of Bratislava (Slovakia), where the cargo was transferred to a ship and continued to China. This transport had been planned for more than 9 months due to infrastructure issues. The transport of cargo alone cost over EUR 400,000; $80 \%$ of this price was the financial costs of modifications of infrastructure (modifications of urban roads, roads, support of bridges, etc.), and only $20 \%$ of this amount was the price of the transport by ship. This is a transport that was monitored as a part of the research and it was carried out by the company NOSRETI [13].

The cause of problematic transports of cargoes is the current trend of calming the traffic using construction elements that limit the passage of vehicles [14-16]. This includes the design of various types of roundabouts [17-21], narrowing of roads and the creation of speed bumps on through roads in cities and villages and the modifications of roads to ensure safe cycling [22-24], but also the regulation of traffic at crossroads, junctions and interchanges. Complications are also caused by fitting the elements of telematic applications on roads. At present, the state of the communication network is increasingly unsatisfactory for the need of passage of oversized cargoes in the Czech Republic. All carriers of excessive cargoes regularly face this fact when preparing transport routes.

Similarly, the situation is complicated in many other European countries, although there exists the European Best Practice Guideline for Abnormal Road Transport of 17 May 2006 [1], which recommends member states build a Europe-wide network of corridors for the transport of excessive cargoes.

As already mentioned, the road network is not designed for these transports in many European countries. There is a complete lack of backbone routes on which the spatial requirements for the passage of transport would be ensured. At present, the most detailed conditions for excessive transport according to the directive [1] within Europe are in Finland. In Finland, the sets of standard values and guidelines for dimensioning the infrastructure of roads were created [1,23-29]. Regulations from the Netherlands, Germany [30] and the USA [31] concerning the design of roads were also examined. None of these regulations determined parameters for ensuring transports, which could be used as a model for creating the regulation in the Czech Republic. 
For these reasons, research aims were set to ensure a functional and sustainable transport infrastructure for the transport of excessive and oversized cargoes. The authors of the article addressed several research projects (the individual parts of the research are published in $[11,12,32,33])$, which set out individual hypotheses and aims for achieving the desired outputs. These include the determination of backbone routes within the Czech Republic, the creation of software models of vehicles for the verification of swept paths and the determination of geometric parameters for the design of a communication network. The suggested solution must not influence the other participants in the traffic from the perspective of their safety [34-38].

To understand the problem, measurements were performed during the transports of oversized cargoes [11,12,33]. These measurements were performed not only in the Czech Republic but also abroad (Slovakia, Poland, Germany, Austria, Slovenia, Hungary, Ukraine). Companies dealing with transport and escorts of the mentioned cargoes were contacted [11]. Subsequently, the data from the performed measurements were analysed and evaluated using statistical and mathematical methods. These included research into the types of transported cargoes, identification of sources and destinations of transports, as well as video analysis of monitored transports using a system of video cameras, a drone [12,33] and a floating vehicle, similarly as in [37]. The acquired records were also processed using digital image analysis [20,33,39-41]. Furthermore, measurements using GPS technology were used [11] and software models of vehicles were created to determine (verify) the parameters similarly as in [42], which would ensure the passage of transports on roads (the issue is described in more details in the following publications $[11,12,33]$ ).

The aim of the presented article is to acquaint the professional public with the not very well-known and often neglected issue of the transport of excessive and oversized cargoes, given its significant impact on transport infrastructure, economic complexity of transport for both the carriers and especially the investors and the resulting impact on product competitiveness. These research results should be used for the subsequent technical design of the parameters of the communication network in cities to ensure the passage of oversized transports and to verify the critical points of the route. The emphasis is placed on sustainable, safe and economical transport infrastructure.

\section{An Issue of Transports from the Perspective of Urban Transport Infrastructure}

Before analysing the issue of transport from the point of view of sustainable transport infrastructure, it is necessary to define the transport of excessive and oversized cargoes from the point of view of legislation. In the Czech Republic, these values are set as follows [43]: the maximum permitted width of the vehicle is $2.55 \mathrm{~m}$, the maximum permitted height of the vehicle is $4.20 \mathrm{~m}$ and the maximum permitted length of a set with two trailers or a semi-trailer and one trailer is $22.00 \mathrm{~m}$. The maximum permitted weight of the vehicle may not exceed $48.00 \mathrm{t}$. Excessive or oversized transport is such a transport that exceeds the largest permitted dimensions specified by the relevant regulation [43].

On the basis of the conducted research, we can divide the issue of transport of excessive and oversized cargoes in terms of urban transport infrastructure into several basic parts.

\subsection{Selection of Route}

The route for the transport of cargo is chosen by an authorized employee of the carrier, or it may also be an employee of a hired entity (escort employee). The final approval of the proposed route is granted by the competent authority according to legislative regulations.

As the routes are not determined from the point of view of logistics of the transport of cargo, the suggestion of the route is based on previous facts or finding out the condition of the route directly in the field. The carrier is obliged to check the chosen route the day before the transport and is responsible for its selection. It is important to know all the parameters of the transported cargo when choosing the route and the type of low-loader. This proposal of the route can take several months. 


\subsection{Traffic Signs}

Traffic signs are one of the most common issues when passing with oversized cargoes. Traffic signs are placed in most cases in close proximity to the road, where it prevents the passage of oversized cargoes. These traffic signs must be dismantled and restored to their original condition after the passage. However, the traffic signs are often fixed, making such manipulation impossible. It is suitable to use demountable traffic signs on these frequent routes. However, some complications can also occur here. These are mainly anchor bolts mounted on the foot, which is anchored to the concrete foundation. A post support with a traffic sign is then fitted to this foundation. These anchor bolts protrude and the vehicle cannot pass at this point. It is necessary to underlay these places on the route. However, this solution cannot be always used.

One example is a traffic sign, which is mounted on a boom above the road (newly built/reconstructed pedestrian crossings). The road sign is mounted on a solid structure of the boom (see Figure 1). The structure is welded and this makes it impossible to turn any unloading during the passage. In such cases, time and financial losses arise.
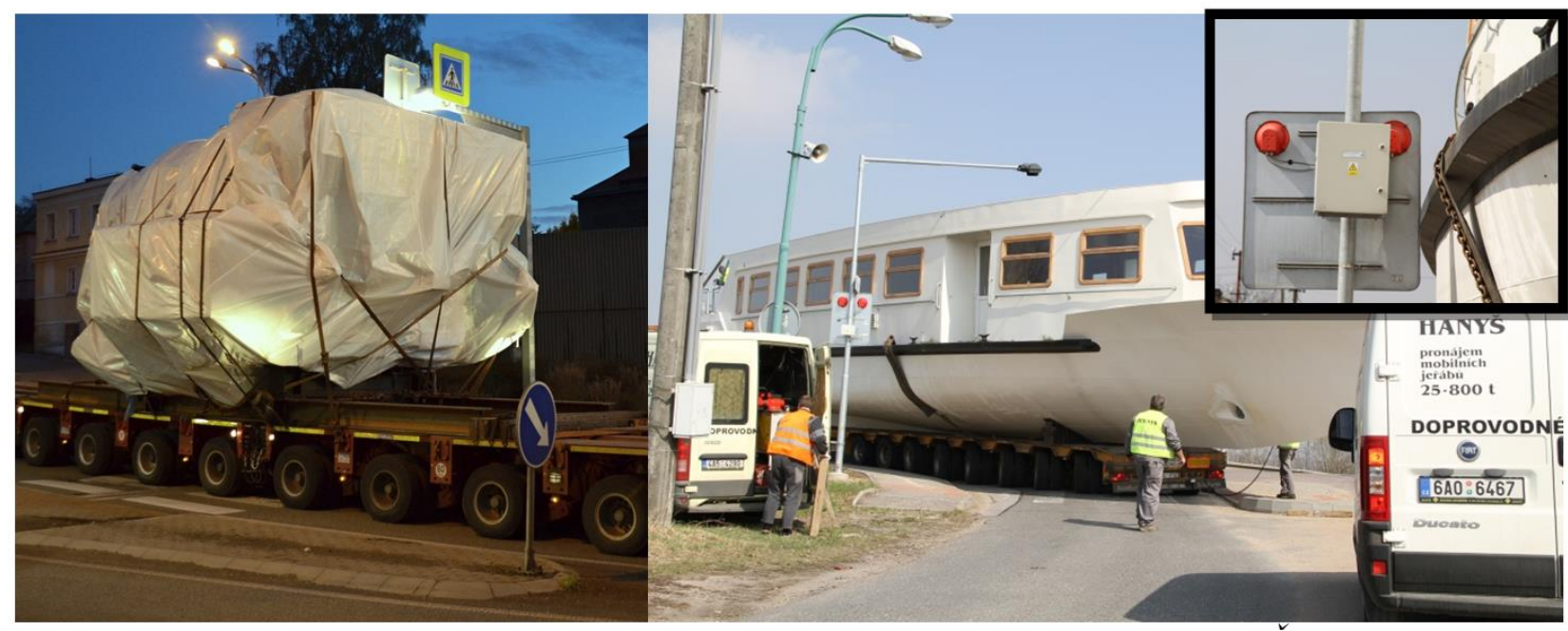

Figure 1. Examples of some problematic places of traffic signs [11].

\subsection{Elements and Structural Solution}

These elements can include lighting, traffic islands, elevated curbs, railings and other non-mobile elements. If we focus on lighting of roads, we find that it is closely linked to traffic signs. Additionally, here the carriers are faced with too close proximity of the location of the lighting pole to the road. Subsequent disassembly is very complicated due to the connection to the electricity distribution network and it requires the need of professional staff.

The most problematic places are the newly built or even existing islands on the roads. The islands narrow the width of the road and divide it in the height. In these cases, the use of underlayment is necessary, but this measure cannot always be implemented. In such cases, the section or the intersection become impassable for the set. Examples of individual structural elements for the passage of an oversized set are shown in Figure 2. 


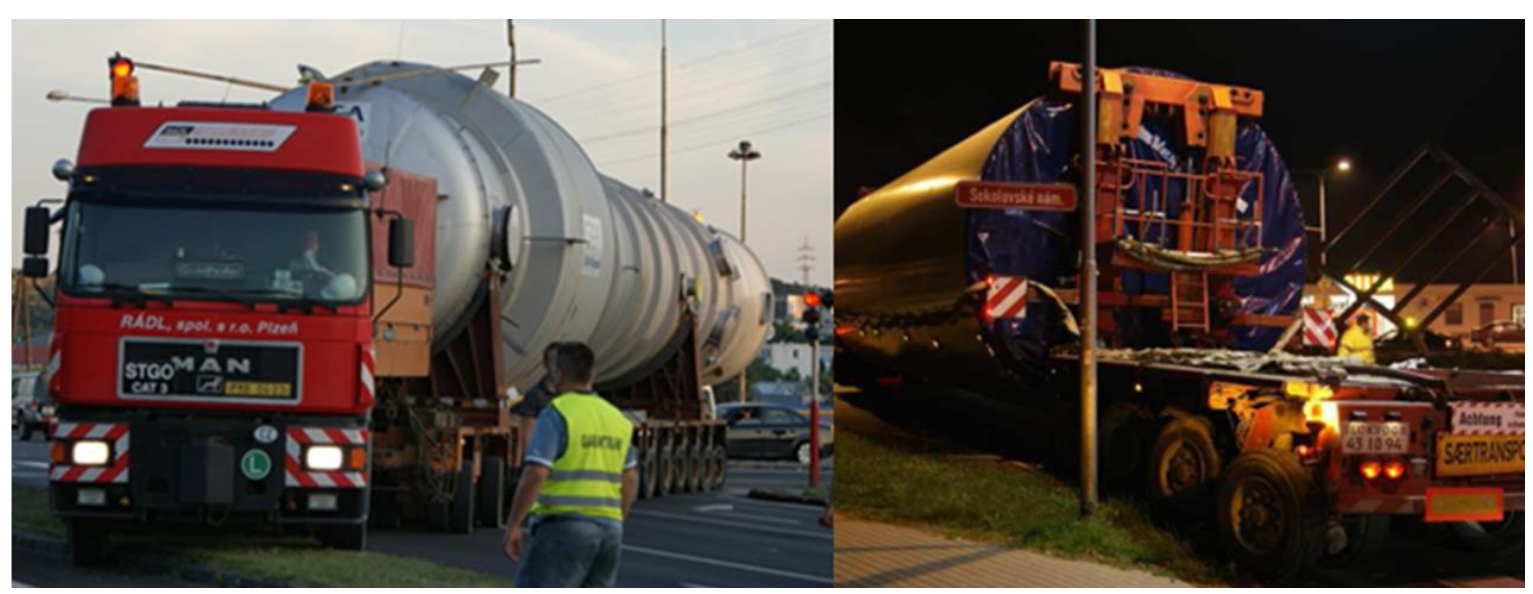

Figure 2. Problematic elements and structural solutions during the transport of an oversized cargo [11].

\subsection{Bridges}

Routes for transport are also chosen with respect to bridges. It is not only their load capacity, but also the headroom. Insufficient load capacity of bridges makes it impossible to lead the route in favourable spatial parameters for excessive transport. If we do not take into account the current state of the bridge and just talk about the design itself, we will find that the bridges are not designed for such loads. Standards ČSN EN 1991-2 [44] and ČSN 736222 [45] stipulate a vehicle with an exceptional load on bridges on which the passage of these loads is assumed.

The condition of the bridges is monitored before the passage of the set and a static recalculation of the bridge is performed. When the set passes through, the deflections and deformations of the bridge deck are monitored again. Some bridges must be supported during transport.

These tasks require a considerable amount of time, but also a large financial burden for the final customer. The price of the product increases and thus reduces its competitiveness. The paradox is that the same bridges must be supported several times a year. After the transport, the bridges are restored to their original condition without any improvement in their construction condition. It is also a misapprehension that load of excessive cargoes causes more damage to the bridge than the normal operation at the same time. In many cases, the opposite is true. One of the conditions for the passage of cargo over bridges is that the transport must not change the original condition.

Bridges are also related to their headroom, which is determined in the Czech Republic according to the standard ČSN 736201 Design of Bridges 2 [46]. The standard states the heights on the following types of roads:

- Motorways, expressways and roads of 1st and 2nd class-4.80 m;

- Roads of 3rd class and local express and local distributor roads-4.50 m;

- Local service roads and public service roads-4.20 m;

- Underpasses under light conveyor bridges and similar equipment, safety nets, pipelines and other lines- $5.85 \mathrm{~m}$.

\subsection{Toll Gates, Power Lines and Other Lines}

The carriers very often encounter the issue of heights at toll gates and lines. The headroom prevents the passage of the cargo on individual roads and often requires the assistance of other entities.

In the case of toll gates, they are standardly designed for a headroom of $5.50 \mathrm{~m}$. Excessive cargoes, despite the usage of the most modern types of low-loaders, require a higher height. Therefore, we can also find portals adapted for such transports on the road network. However, these toll gates are not often suitably installed into the routes 
of oversized cargoes. If it is necessary to allow the passage of oversized cargo under one portal, the informative price is set at EUR 2500.

Power lines, contact lines and cables complicate the transport in many places. In these cases, the assistance of experts must be ensured (see Figure 3). The cables are lifted during the transport. There are also situations where it is necessary to turn off the electricity network.

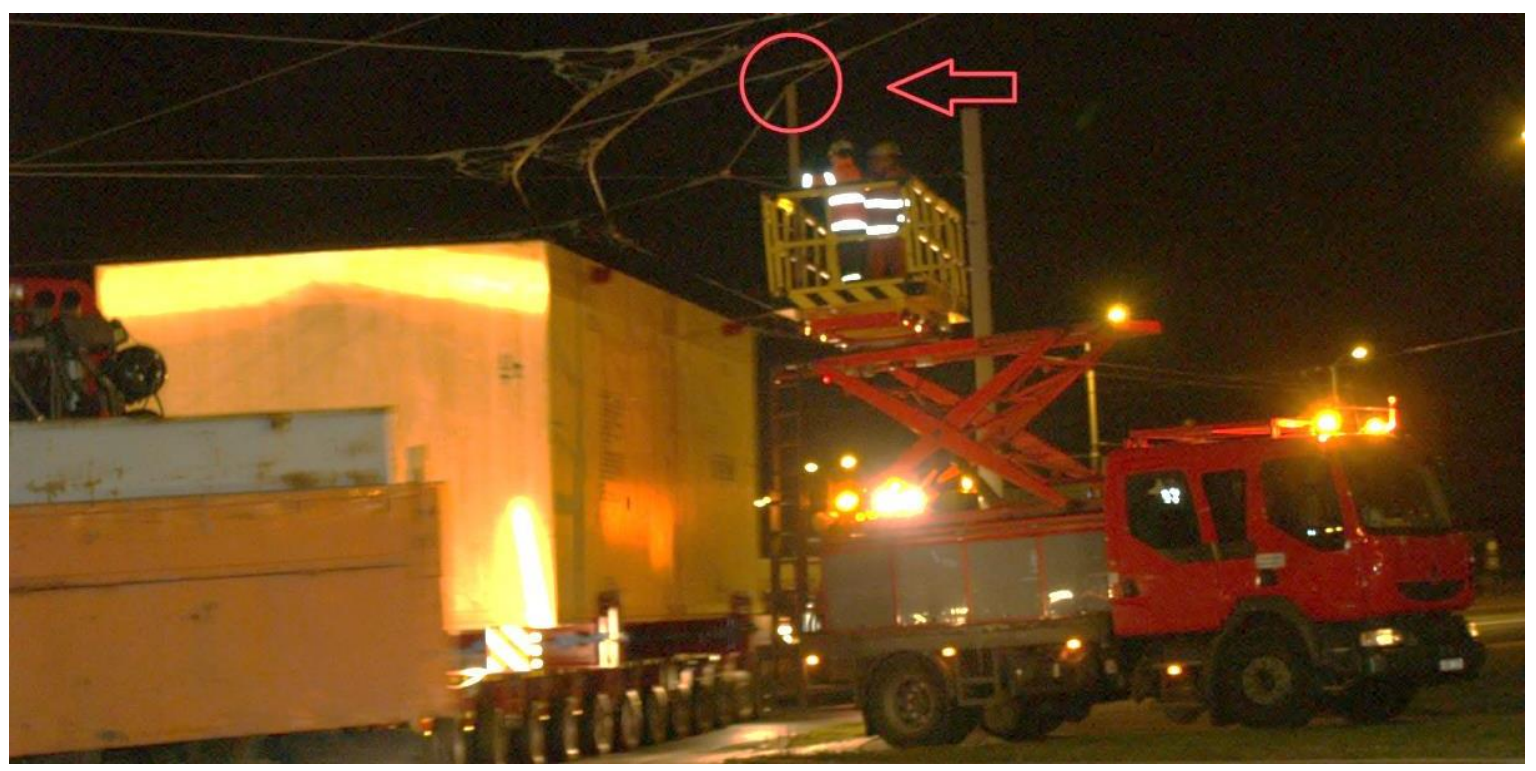

Figure 3. Assistance of the Public Transit Company in transporting the excessive cargo and supporting traction lines in problematic places [11].

\subsection{Level Crossings and Interchanges}

In the case of level crossings, such as rail crossings or places where there is a crossing of a road with a tram line, there arises the problem of underpass under traction lines.

At interchanges, there are many complications in the transport of excessive and oversized cargoes. For these cargoes, it is necessary to have sufficiently large track alignments of the branches of the intersections. It is also important to have enough width of the branches to manoeuvre the set. The headroom under the bridges is also connected to the interchanges. The issue of traffic signs, lighting and dividing islands is already mentioned in the text.

\subsection{Roundabouts}

This type of intersection is widely used on roads. Roundabouts are especially used in municipalities, cities $[47,48]$ and also on important roads. When designing this type of intersection, oversized transport is usually not considered.

Particularly problematic are the parameters of the corners of roundabouts, their size, complications with an elevated central island and dividing islands. The greenery at the edges of the roundabouts can also cause considerable complications.

An example is the roundabout in the town of Prelouc (Czech Republic). This roundabout is a place of frequent transport of excessive cargoes, especially parts of wind power plants. It is located on the road I/2, where this roundabout cannot be avoided when planning the transport.

In Figure 4, there is a newly modelled vehicle from the forthcoming library of vehicles of oversized and excessive cargoes for verification of the roundabout using the simulation of swept path. 


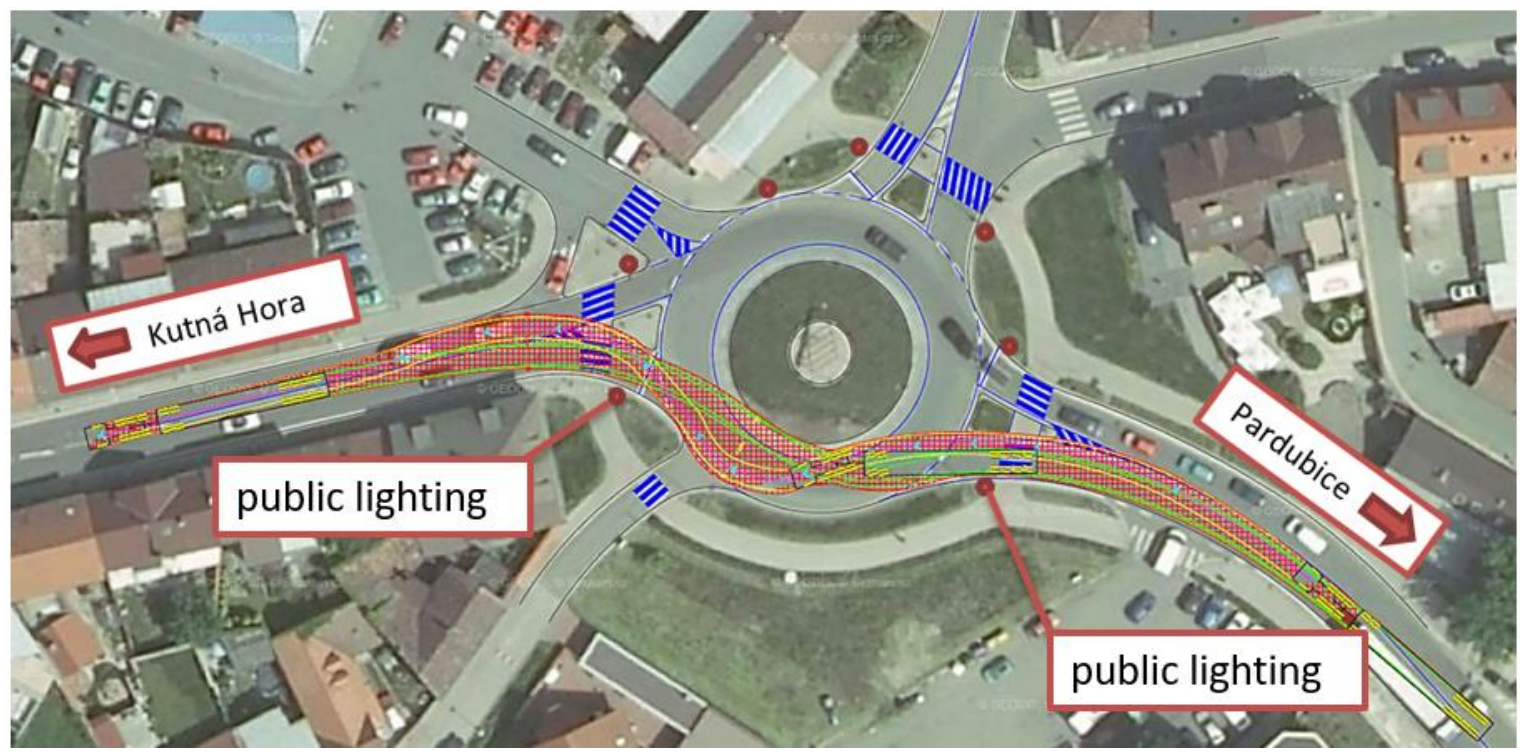

Figure 4. A simulation of passage of oversized cargo through the roundabout in Prelouc (Czech Republic) [11].

The second example is the roundabout in Litomysl (Czech Republic). This roundabout is located on the route of oversized transports. Figure 5 shows an obvious problematic passage, where the vehicle, when exiting the roundabout, crosses an unpaved corner in a width of $2.45 \mathrm{~m}$ and then enters a pedestrian island. The second vehicle is forced to cross a $1.15 \mathrm{~m}$ wide corner when entering this roundabout. The concrete curbs are quite damaged in these places. The curbs are breaking, their parts are falling and the convex from the perspective of traffic safety is not fulfilled.

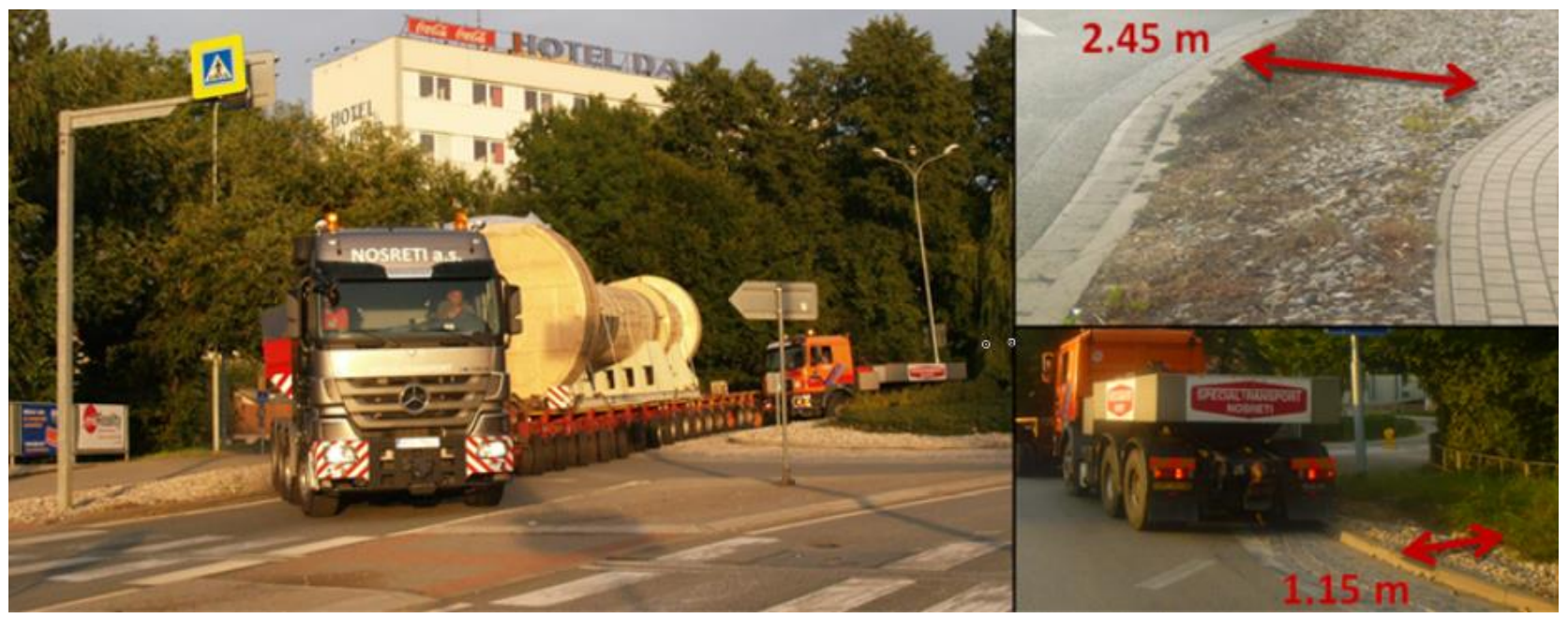

Figure 5. A problematic passage through the roundabout in the city of Litomysl (Czech Republic) [11].

During design or reconstruction, it is necessary to consider the passage on the frequent routes of these transports, so that the set can use the riding in the opposite direction. Another measure is the introduction of truck aprons and the reduction of the curb of the central island. The roundabouts are very often driven through in a straight direction. In these cases, the introduction of a passage through the central island can be used. We must also not forget the measures that are already described in the previous paragraphs with traffic signs, traffic lights or poles of public lighting. 


\subsection{Exit from the Production Plants}

We encounter problematic places not only on the roads, but also when leaving directly from the production plants. This situation is documented in Figure 6, which shows an obviously problematic exit, in which the corners were underlaid with steel plates and several flat tires occurred on the low-loader. It is very difficult to replace them when the cargo is loaded. It often happens because when designing the halls, exits and communications of plants, the transport of these products is not considered. It is important to realize that it is not only the dimensions of the product itself that are decisive, but also the overall dimensions of the set that will transport this product.

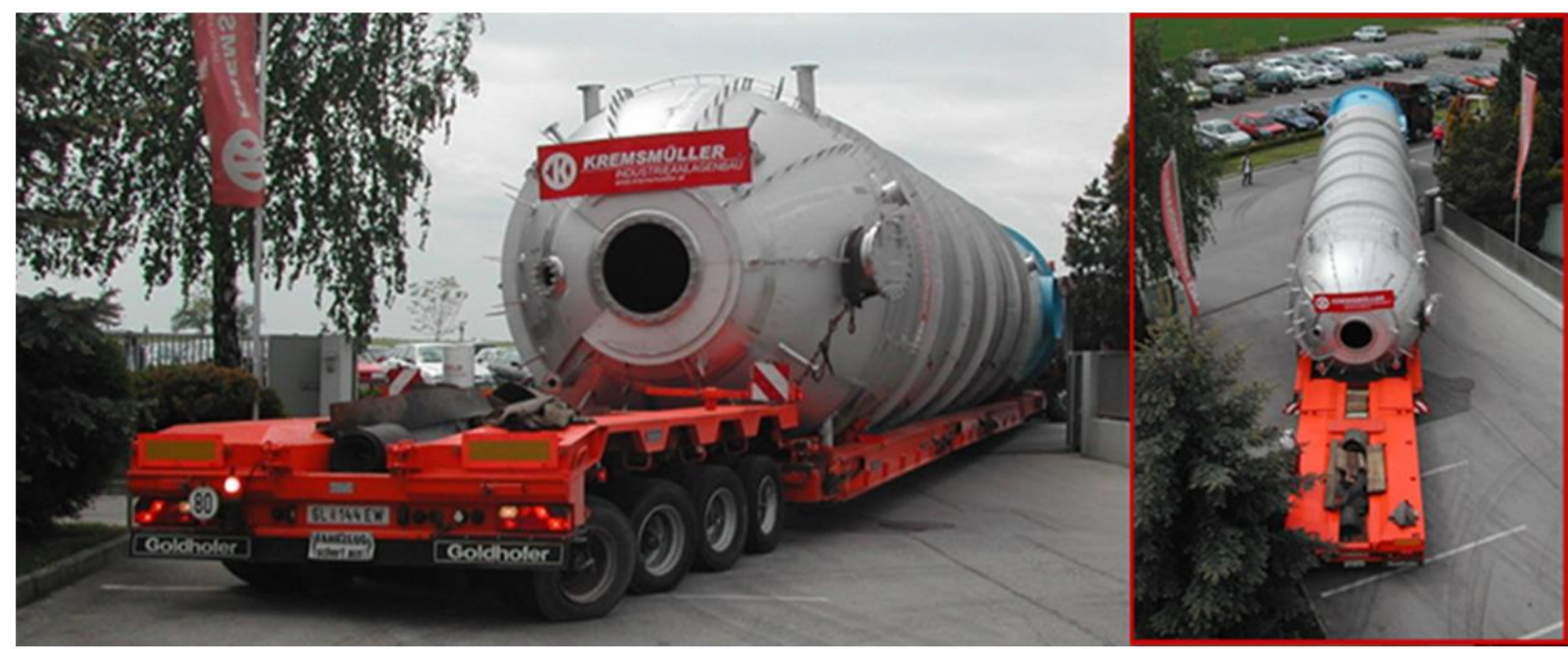

Figure 6. A problematic exit during the transport of the tank to Ruzomberok (Slovakia) [11].

\section{Statistical Data for Determining Technical Parameters of Transport Infrastructure}

To determine the necessary data and parameters, a sample of 519 transports (performed in the Czech Republic, see Table 1) and 556 transports realized abroad (Slovakia, Poland, Germany, Austria, Slovenia, Hungary, Ukraine) were processed within the research. It was an analysis of the used type of chassis and their parameters-the collection of data (lengths, widths, turning radii, usage of pushing and other necessary technical parameters). Furthermore, there was an analysis of the transport costs- the collection of data (length, width, height, weight) from the performed transports. To determine the source and destination of the transports the beginnings and ends of the routes, detailed itineraries of the route and the number of the days of transport were observed.

These are transports of generators, transformers, structures, beam girders, parts of bridges, presses, construction machinery, cranes, machinery and parts and other types of transports, which by the size or weight can be considered as non-standard transport and must obtain a permit. The following graphs show a comparison of data from transports realized in the Czech Republic and transports from abroad. Figure 7 shows a comparison of the lengths of oversized cargo transports, Figure 8 shows the comparison of heights of transports, Figure 9 compares the widths of transports and Figure 10 compares the weights of transports. These statistics were further analysed (for example as [49]) and processed to determine the parameters of backbone routes. 
Table 1. An example of statistical data of realized transports in the Czech Republic (519 transports).

\begin{tabular}{|c|c|c|c|c|c|c|c|c|}
\hline $\begin{array}{c}\text { Type of } \\
\text { Cargo }\end{array}$ & Weight $[t]$ & Length [m] & Width [m] & Height [m] & $\begin{array}{l}\text { Start of } \\
\text { the } \\
\text { Route }\end{array}$ & $\begin{array}{l}\text { End of } \\
\text { the } \\
\text { Route }\end{array}$ & $\begin{array}{c}\text { The Course of } \\
\text { Route (Beginning, } \\
\text { Intermediate Place, } \\
\text { End) }\end{array}$ & $\begin{array}{l}\text { Number } \\
\text { of Days }\end{array}$ \\
\hline $\begin{array}{l}\text { Machine } \\
\text { equipment }\end{array}$ & 40.00 & 17.00 & 6.00 & 4.40 & Brno & Melnik & $\begin{array}{c}\text { Brno-Slatina-D1- } \\
\text { Pruhonice- } \\
\text { Praha-Melnik } \\
\text { harbour }\end{array}$ & 2 \\
\hline Generator & 232.40 & 36.00 & 4.95 & 5.50 & Plzen & Melnik & $\begin{array}{c}\text { Plzen-Krimice- } \\
\text { Mesto } \\
\text { Touskov- } \\
\text { Únesov-Touzim- } \\
\text { Bochov- } \\
\text { Lubenec-Bukov- } \\
\text { Krusovice- } \\
\text { Revnicov-Msec- } \\
\text { Turany-Slany- } \\
\text { Jesin-Nova } \\
\text { Ves-Spomysl- } \\
\text { Melnik }\end{array}$ & 1 \\
\hline $\begin{array}{l}\text { Machine } \\
\text { equipment }\end{array}$ & 60.00 & 33.00 & 4.00 & 4.00 & $\begin{array}{l}\text { Ceske } \\
\text { Bude- } \\
\text { jovice }\end{array}$ & Pisek & $\begin{array}{c}\text { C.Budejovice- } \\
\text { Tabor-Milevsko- } \\
\text { Milin-Velka } \\
\text { Chuchle, I/19, } \\
\text { Pisek }\end{array}$ & 1 \\
\hline
\end{tabular}

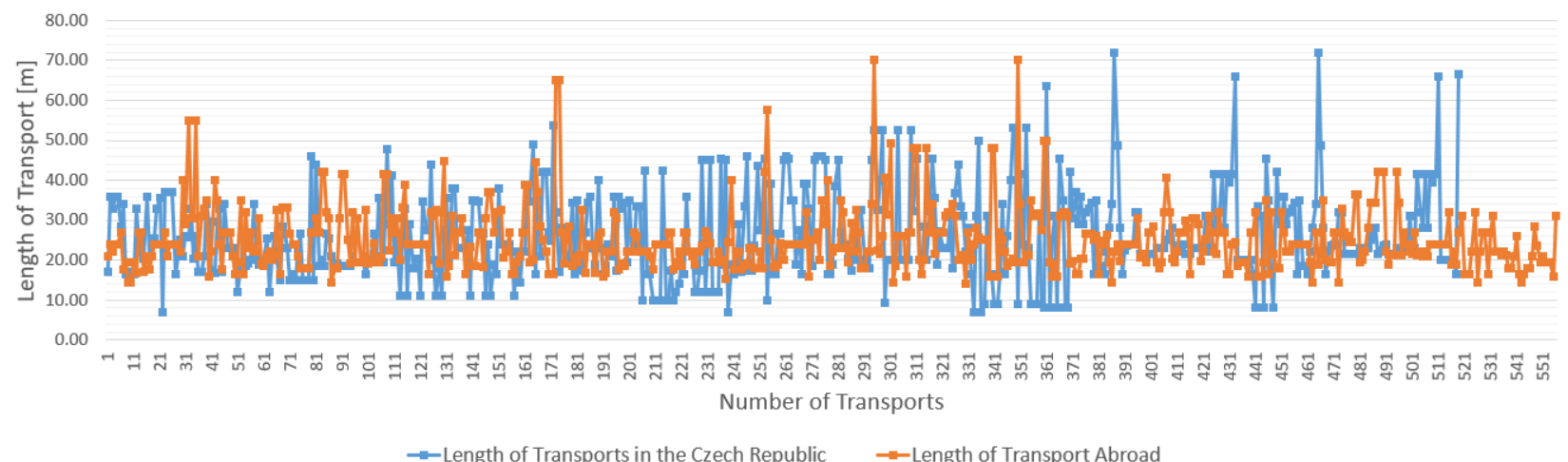

Figure 7. A comparison of the length of oversized cargoes.

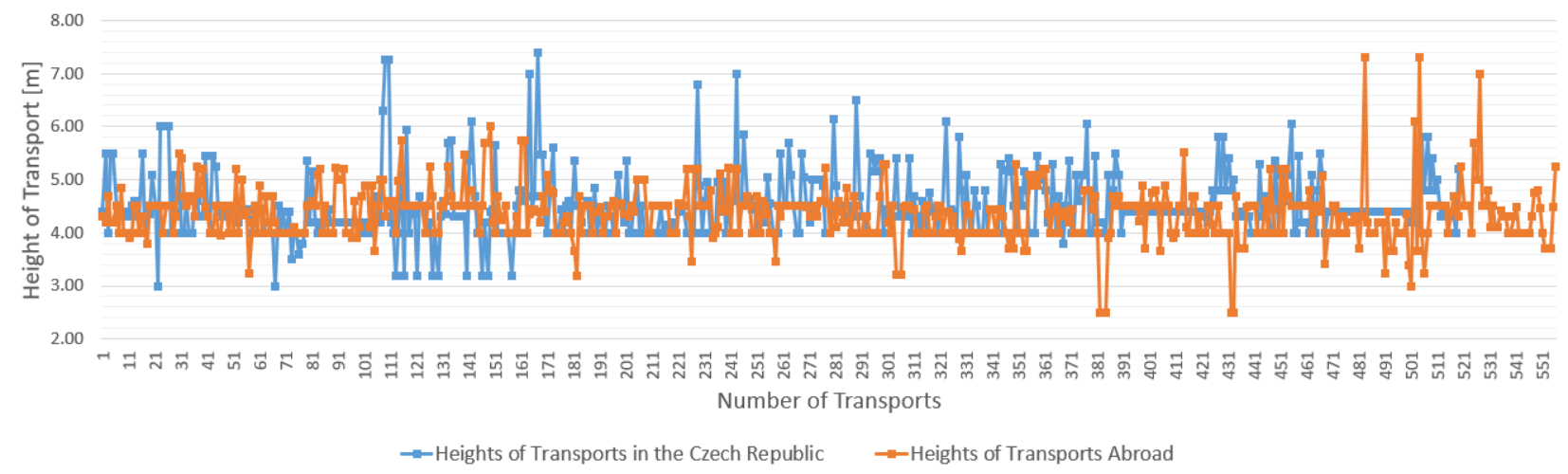

Figure 8. A comparison of heights of transports of oversized cargoes. 


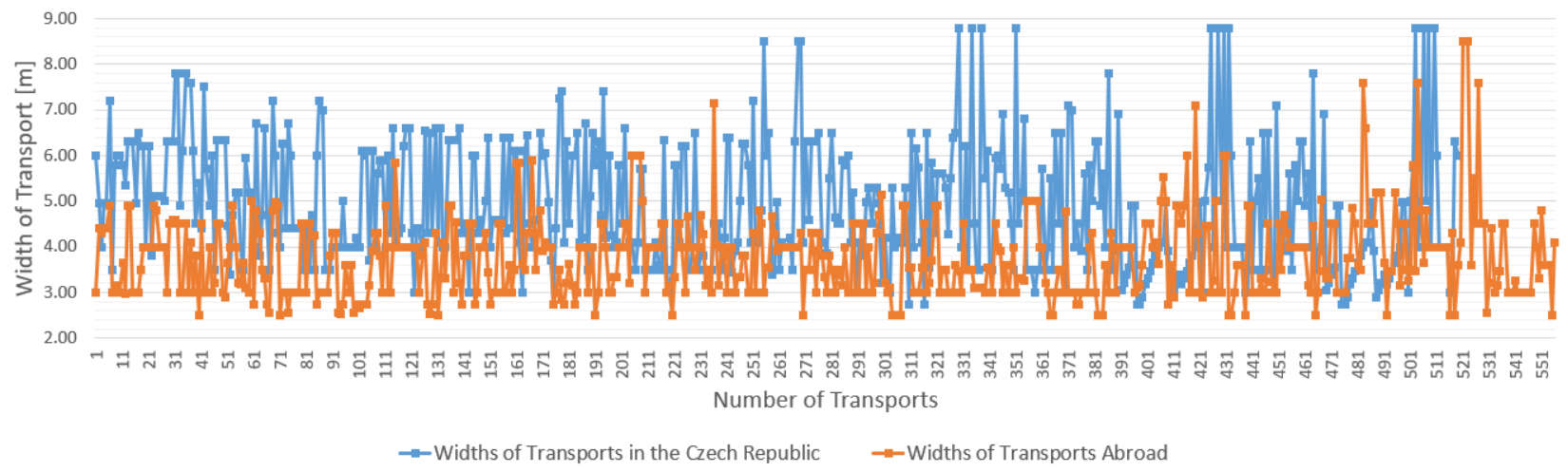

Figure 9. A comparison of width of oversized cargoes.

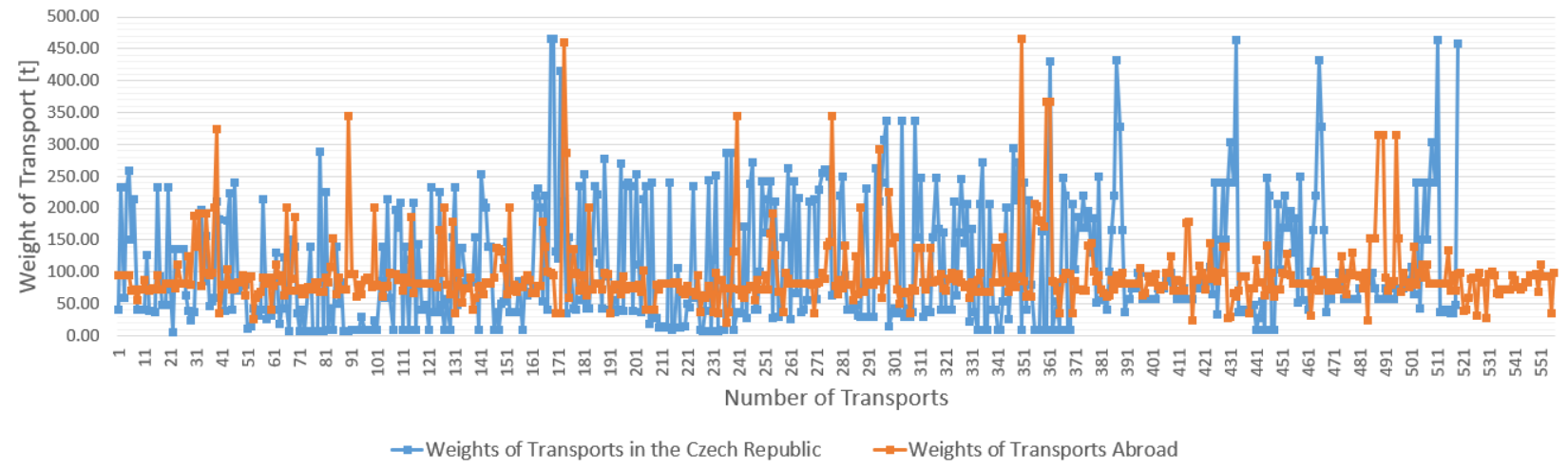

Figure 10. A comparison of weights of oversized cargoes.

From statistical data, the sources and destinations of transport were analysed. These statistical data were supplemented by data from the Police of the Czech Republic, major manufacturing companies and associations of companies transporting oversized cargoes, as well as companies that provide escorts of these transports, ports of the Czech Republic, individual road administrators, etc.

The sources and destinations included manufacturing companies (ironworks, the production of bridges, machinery manufacturing, construction companies, large companies producing oversized products—swimming pools, building cells, technological equipment), factories and nuclear power plants. Ports and border crossings are among the most important sources and destinations of transport.

All this was based on data obtained from the administrators of individual roads and data that were measured during the actual monitoring of transported cargoes. Furthermore, this analysis was supplemented by data from the CleveRa system [50] (it is a comprehensive system of services and applications intended for owners or property managers of roads at all levels-local (cities and municipalities), regional (regions) and state (the Directorate of Roads and Motorways of the Czech Republic, Ministry of Transport, which contains data on diagnostics, registration, evaluation and compilation of documents for road management)). The communication network was also analysed in terms of the bearing capacity of bridges, based on data from the BMS system (bridge management system) [51]. On the basis of these data, and from the processed statistics (beginnings and ends of transports-the course of the route itself) and other information about other entities (the Police of the Czech Republic, carriers of oversized cargoes, escorts), backbone routes were suggested, which should meet the parameters for transports of these cargoes. These routes would be protected and newly prepared constructions and reconstructions would have to meet the required (set) parameters. The routes also follow the transport routes of foreign carriers transporting cargo through the Czech Republic. These aims are set out in more detail in the forthcoming 
materials, which will be used by designers of transport constructions. Therefore, emphasis was placed on sustainable, safe and economical transport infrastructure not only within cities but also throughout the whole communication network. The created map of the backbone routes of the Czech Republic is shown in Figure 11.

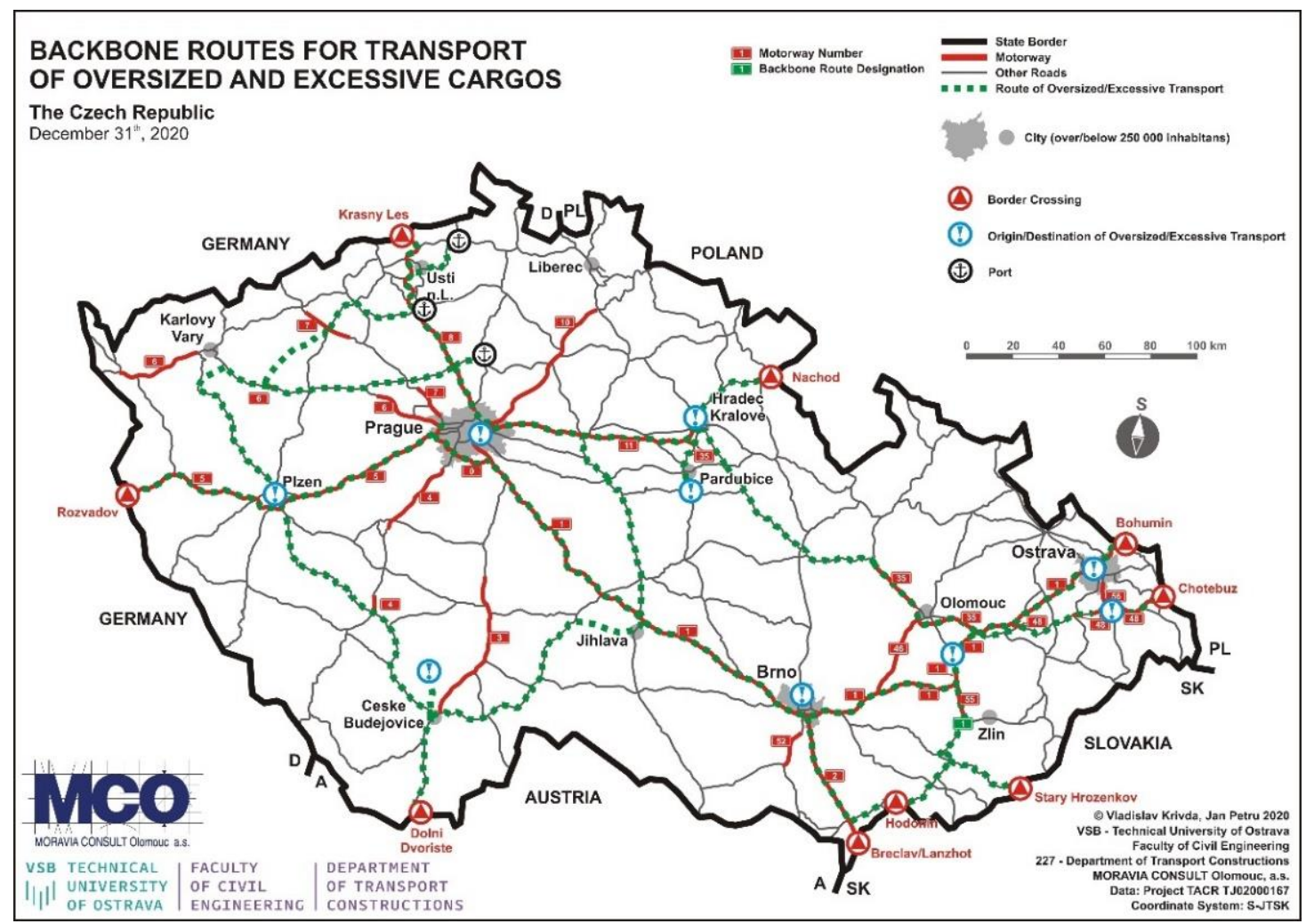

Figure 11. The created map of the backbone routes of the Czech Republic.

\section{Measurement and Modelling of Vehicles of Oversized and Excessive Cargoes}

To ensure the technical and construction parameters of roads, modelling of vehicles transporting excessive and oversized cargoes was approached [11,12]. The modelling of the vehicles took place mainly due to the fact that there was no library of excessive and oversized cargoes for the verification of swept paths in any available software. Although the programs for the verification of swept paths contain some vehicles, these vehicles did not correspond to vehicles moving on roads in Europe, or their parameters did not correspond to vehicles according to our analysed statistical data and documents from carriers of excessive and oversized cargoes.

For these reasons, extensive research was conducted to ensure the technical parameters that are necessary to know to create a model in specialized software. Carriers of excessive and oversized cargoes and the companies that manufacture these vehicles (e.g., Goldhofer, Nooteboom, etc.) were addressed.

\subsection{Measurement of Vehicles}

The analysis of technical parameters was not entirely sufficient in some cases and there was a need to determine the real behaviour of a vehicle moving on the road. Therefore, the authors of this article performed a number of measurements using GPS (Global Positioning System) technology, which was fitted to a vehicle transporting excessive and oversized cargoes [11,12]. Special GNSS (Global Navigation Satellite System) equipment was installed on the tractor (cab), on the axis of connection of the tractor to the semi-trailer (connection) and the last equipment was placed on the rear axle of the low-loader (semi-trailer). The location of individual devices was precisely localized for subsequent evaluation. The 
position of the antennas was determined with emphasis on the use of a minimum number of GNSS equipment so that it is possible to construct the outlines of the tractor and semitrailer using the relations of analytical mathematics and information from the technical documentation of the set [11]. The diagram of the location of GNSS devices can be seen from Figure 12.

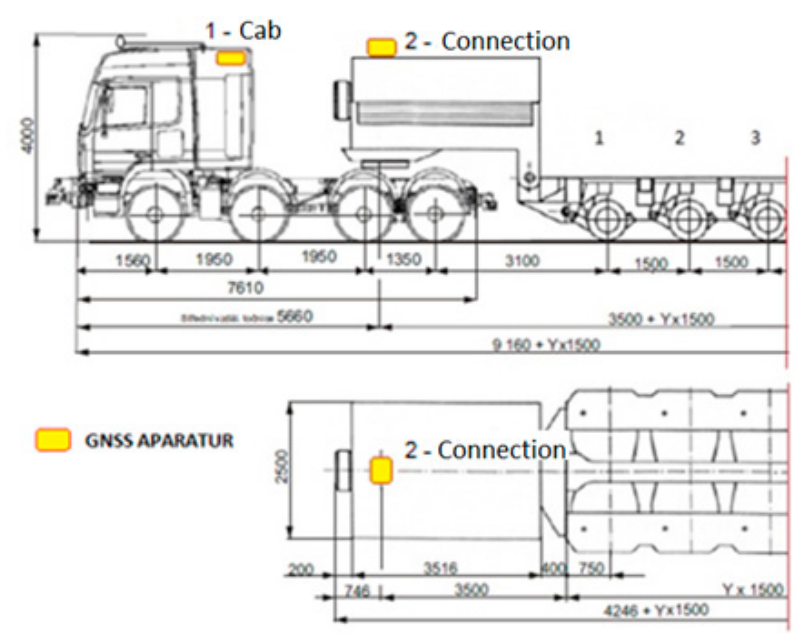

(a)

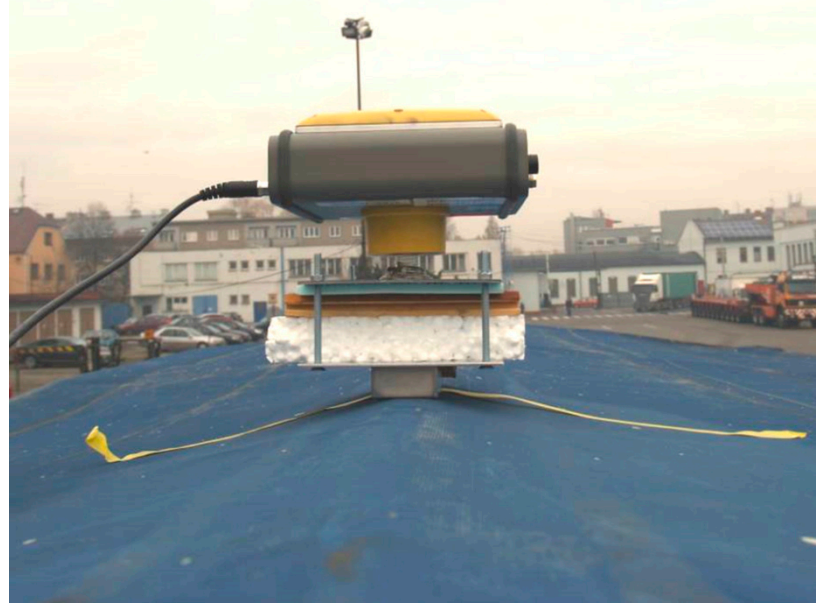

(b)

Figure 12. The position of GNSS apparatus on the vehicle: (a) diagram of location of the apparatus on the cab and connection, (b) photo documentation of GNSS apparatus on the connection, including a specially designed construction for fitting using neodymium magnets and their shielding [11].

The measurement of the actual movement of the vehicle took place on a pre-set polygon along predetermined trajectories. The apparatus was set to collect data at $1 \mathrm{~s}$ intervals. The collection of data was set so that only RTK (real-time kinematic) measurements that took place with the resolution of ambiguities in the length of the measurement base at the level of significance of $99.5 \%$ were accepted as valid. The measurement was performed in the S-JTSK (Krovak East North) coordinate system. The measured data were processed in the ArcGIS Desktop settings. For the calculation of outlines, a script for automation of the evaluation of the measured data was prepared. The result of the processing is a class of $3 \mathrm{D}$ polygon geo-elements (representing the plan view of a tractor and a semi-trailer) and a class of point geo-elements representing the outlines of significant edges in the plan view of a tractor and a semi-trailer. These edges were further analysed in AutoCAD Civil 3D.

In Figure 13a, a part of the processed points from the GNSS apparatus is shown on the basis of the resolution according to time and the resulting measurement, when the measured set performed the whole movement along the determined polygon. These points were then differentiated according to the position on the vehicle Figure 13b:

- 1_GPS_NLE_-points representing the rear edge of the semi-trailer on the left side;

- 1_GPS_NLS - points representing the front edge of the semi-trailer on the left side;

- 1_GPS_NPE_-points representing the rear edge of the semi-trailer on the right side;

- 1_GPS_NPS - points representing the front edge of the semi-trailer on the right side;

- 1_GPS_TRACTOR_POINTS—points that represent the front edges of the can on the right and the left side (rear points cannot be used due to the fact that the modelled vehicles in AutoTURN program do not show the end of the rear edge of the tractor. To determine the exact position, the axes were used);

- 1_GPS_AXIS_TRACTOR-points of the tractor (cab);

- 1_GPS_AXIS_SEMI-TRAILER—axis of the semi-trailer of the measured low-loader. 


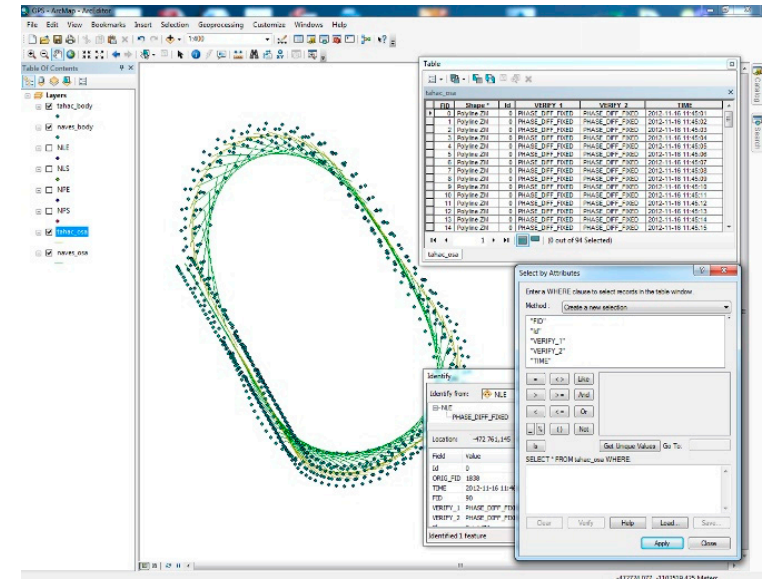

(a)

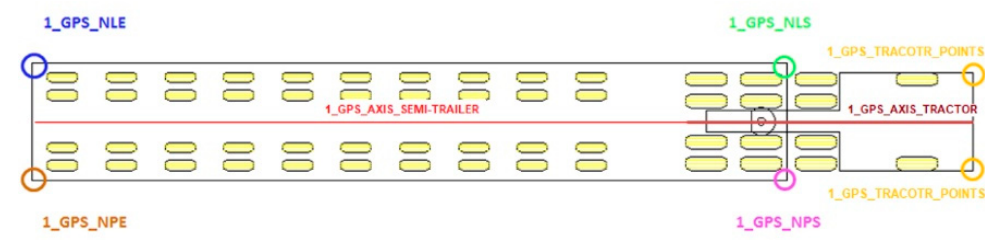

(b)

Figure 13. Output from the GNSS apparatus: (a) part of processed data from GNSS apparatus, (b) resolution of points according to position on the measured vehicle.

Within the scope of the measurement, UAV (Unmanned Aerial Vehicle) technology was used, where the movement of the vehicle was recorded $[30,34]$ with the help of a drone. This movement was subsequently processed using image analysis in specialized programs $[39,40]$ and further verified with output with GPS measurements. Verification showed the concurrence of individual results and the differences in the swept paths were minimal in the tolerance for determining the error. Therefore, data from GNSS apparatus can be considered relevant for the creation and verification of the vehicle in the programs for the analysis of the swept paths.

\subsection{The Modelling of the Vehicle and the Verification of the Vehicle}

From our processed analyses of excessive and oversized cargoes, individual types of vehicles were created, which we divided into six categories. A detailed description of the individual categories is published in [12]. These categories were determined on the basis of types of transported cargoes, types of chassis, etc. The categorization of vehicles took place mainly due to the fact that it is not possible to determine the routes for only one type of vehicle, but it is necessary to approach the design of parameters comprehensively. On some routes, for example, only generators and transformers are transported, while on other routes only parts of structures or machinery are transported. It is true that different types of transport require different parameters of intersections. Therefore, it is not always necessary to have routes and its parameters created for all types of transport.

The modelling of vehicles itself took place in programs for determining the swept paths (AutoTURN, easyTrack, AutoPATH). These programs have the option of creating user vehicles and the basis of entering their technical parameters. Once the vehicles were created, they were verified. The verification was performed according to processed and evaluated measurements using GPS technology. A comparison of swept paths of the modelled vehicle with the movement of the real vehicle (GPS measurements), including an example of the model of the created vehicle in the AutoTURN program, can be seen in Figure 14.

On the basis of the measured deviations of individual points from the newly created vehicle and measurements with GNSS apparatus, we can conclude that the modelled vehicle in AutoTURN program corresponds to the "real behaviour" of the vehicle transporting excessive and oversized cargoes, which was used in the measurement. 


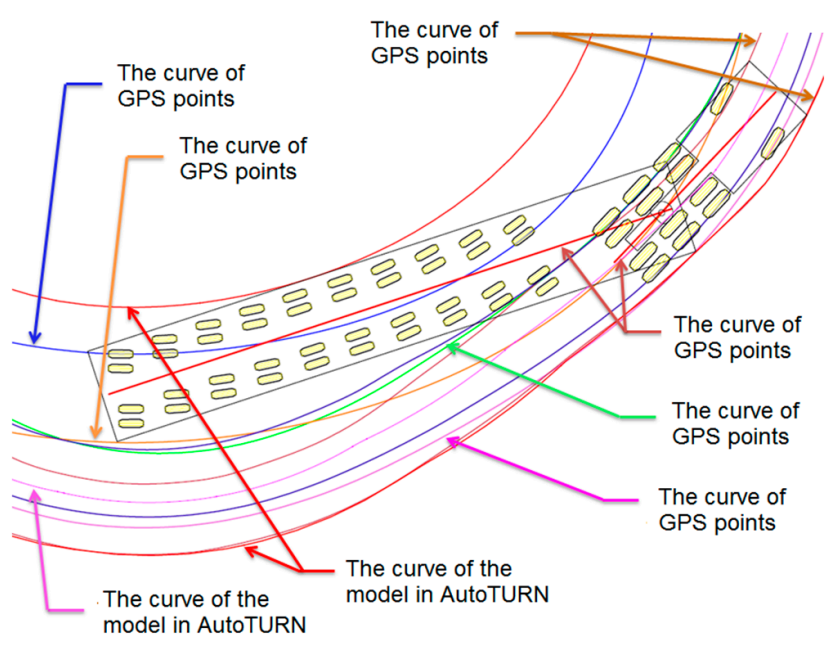

(a)

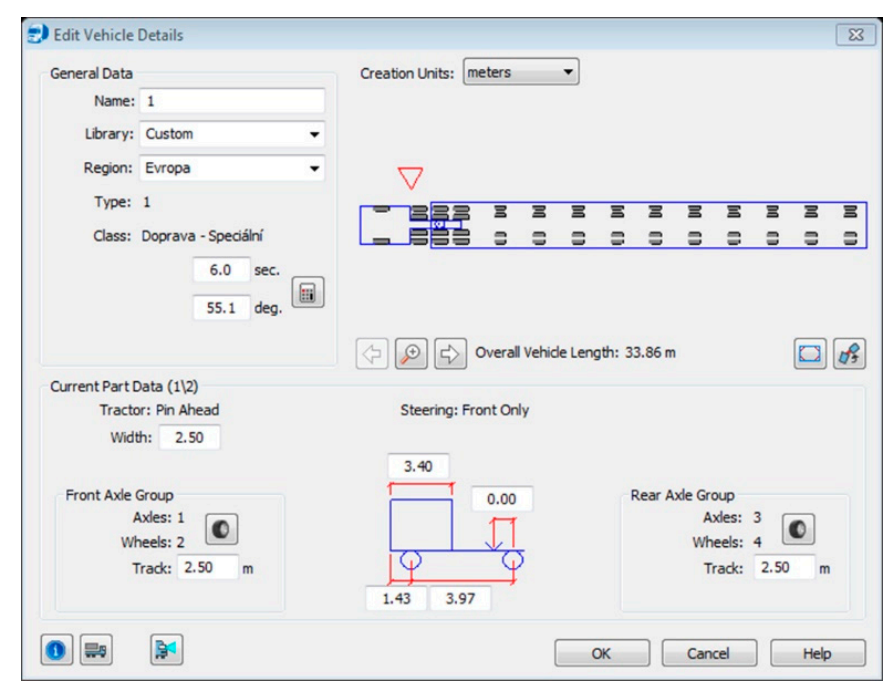

(b)

Figure 14. Verification and modelling of the vehicle: (a) a display of deviations of individual edges of the low-loader AutoTURN/GPS measurement, (b) modelling of a newly created vehicle in the AutoTURN program.

To complete the values, the minimum and maximum values of deviations for the individual edges of the semi-trailer and the edges of the tractor are given.

- 1_GPS_NLE-min. $12 \mathrm{~mm}$, max. $41 \mathrm{~mm}$;

- 1_GPS_NLS-min. $5 \mathrm{~mm}$, max. $27 \mathrm{~mm}$;

- 1_GPS_NPE-min. $23 \mathrm{~mm}$, max. $46 \mathrm{~mm}$;

- 1_GPS_NPS—min. $12 \mathrm{~mm}$, max. $41 \mathrm{~mm}$;

- 1_GPS_TRACTOR_POINTS—min. $2 \mathrm{~mm}$, max. $11 \mathrm{~mm}$.

\subsection{A Simulation of the Passage}

The modelled vehicles were also used in terms of simulation of the passage of the vehicle [35] at a selected intersection in an urban area. The simulation served as another element for determining the necessary technical parameters. For the analysis of the passage, 100 realizations through the crossroad were performed. The picture shows four rupture curves of all simulated passages. These curves contain all performed simulations.

- Blue hatch-passage without the need to dismantle traffic signs, the truck aprons were used for the passage;

- Grey hatch-passage with the need to cross the road curbs and use the soft shoulder curbs and greenery;

- $\quad$ Red hatch-a passage that cannot be realized due to passing through the central island, curbs and dismantling of public lighting;

- Purple hatch-the passage, which was recorded during the monitoring of the transport-this is a transport that took place at the intersection-during the passage the traffic signs were dismantled, the road curb was passed and the soft shoulder of the curb were used. However, the excessive cargo did not pass the central island of the intersection.

On the basis of the simulation of the movement of an oversized vehicle at an intersection, the probability of passage was analysed. The Monte Carlo simulation method was applied to these virtual simulations of the movement of the vehicle at an intersection. Swept paths were analysed and the probability of the vehicle leaving the outline of the intersection at individual passages was quantified. The analysis took into account critical points at the intersection, such as the distance of traffic signs, public lighting, road curbs, etc. 
A histogram of the evaluation of the passage of oversized cargo through the roundabout was created. The horizontal axis indicates the total width of the circulatory roadway that can be used for transport. A value of 0 indicates half of this width. The vertical axis represents the frequency of passages. The blue dashed line indicates the border when it is necessary to dismantle the traffic signs and prepare the passage through the intersection. The black dashed line indicates the need to pass the road curb (curbs are underlaid). The red full line indicates the border when the transport is no longer feasible (underlaying is not possible, assistance of many subjects, dismantling of lighting, dismantling of the pole of traffic signs). More detailed results from the research of the authors are given in [11,52]. A simulation of the swept path of the vehicle and the histogram of probability of the passage is shown in Figure 15.

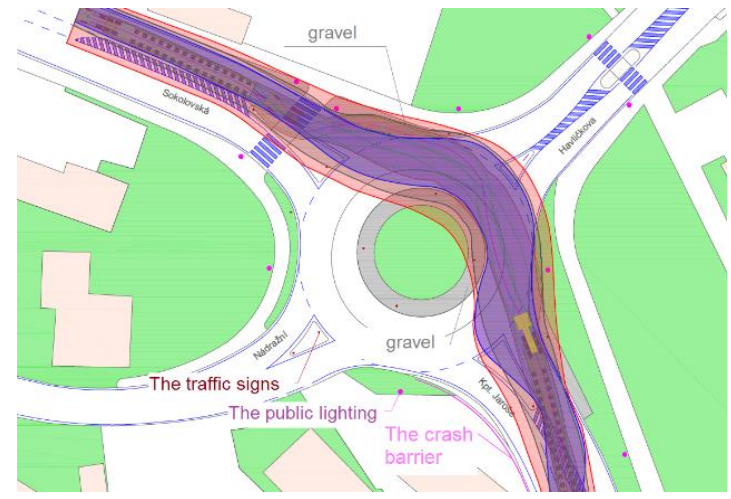

(a)

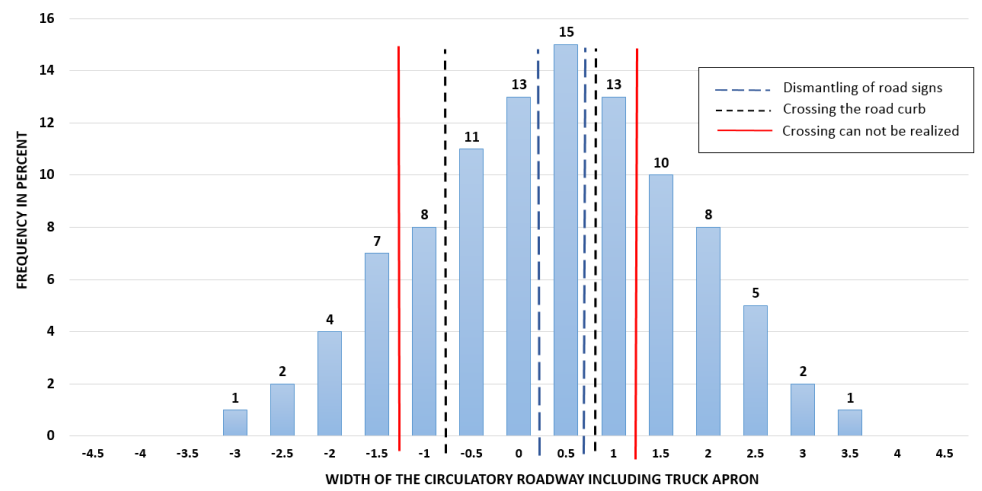

(b)

Figure 15. Verification and modelling of the vehicle: (a) a display of deviations of individual edges of the low-loader AutoTURN/GPS measurement, (b) a modelling of the newly created vehicle in the AutoTURN program.

The simulation of the passage clearly shows us the demands on the passage of excessive and oversized cargoes on the city communication network and the overall demands on the transport infrastructure.

\section{Determination of Radii of Arcs at Corners}

The determination of the radii of corners was realized on the basis of simulations of the passages of newly created vehicles in the programs AutoTURN, easyTRACK and AutoPath. The vehicle simulation was performed on predetermined curves and the angles that these curves form. From the perspective of the simulation, the angles were determined at $15^{\circ}$ from the initial angle of $90^{\circ}$ up to $165^{\circ}$. The direct passage of the vehicle was not considered for the simulation, as the swept path of the set does not change at this angle. The radii of the corners, which were determined from the point of view of research, can be used for a simple circular arc at the corners of the intersection, or they can be used to determine the compound arc of the corners of the intersection. These radii can also be used as corner radii at roundabouts on entry/exit branches. The detailed Table 2 shows resulting values with corners radii according to the used low-loader and relevant category to which the low-loader belongs was created from the verified simulations of swept paths [11]. It is important to note that, for example, the low-loader THP-SL long-load combination with a length of $42.52 \mathrm{~m}$ consists of a tractor and two separate low-loaders, which are connected to each other by a frame construction. Separate low-loaders can be independent of each other (i.e., they do not have to pass the same route). 
Table 2. A detailed table of corner radii according to the used low-loader and category.

\begin{tabular}{|c|c|c|c|c|c|c|c|c|c|}
\hline \multirow{3}{*}{ Category } & \multirow{3}{*}{$\begin{array}{l}\text { Type of Used } \\
\text { Low-Loader }\end{array}$} & \multirow{3}{*}{$\begin{array}{l}\text { Length of } \\
\text { the Set (m) }\end{array}$} & \multirow{3}{*}{$\begin{array}{c}\text { Width of the } \\
\text { Low-Loader }(\mathrm{m})\end{array}$} & \multicolumn{6}{|c|}{ Angle of the Approach of the Vehicle $\left(^{\circ}\right)$} \\
\hline & & & & $\begin{array}{c}90 \\
(90)\end{array}$ & $\begin{array}{l}105 \\
(75)\end{array}$ & $\begin{array}{l}120 \\
(60)\end{array}$ & $\begin{array}{l}135 \\
(45)\end{array}$ & $\begin{array}{l}150 \\
(30)\end{array}$ & $\begin{array}{l}165 \\
(15)\end{array}$ \\
\hline & & & & \multicolumn{6}{|c|}{ Radii of Corner R (m) } \\
\hline $\begin{array}{c}\text { - Heavy } \\
\text { Transports } \\
\text { - Components }\end{array}$ & $\begin{array}{l}\text { Goldhofer } \\
\text { STHP/LTV }\end{array}$ & 33.87 & 3.00 & 17 & 22 & 35 & 46 & 95 & 160 \\
\hline $\begin{array}{l}\text { - Constructions } \\
\text { - Mix Category }\end{array}$ & STZ-H10 axles & 33.87 & 2.75 & 27 & 36 & 52 & 73 & 120 & 185 \\
\hline $\begin{array}{l}\text { - Constructions } \\
\text { - Mixed Category }\end{array}$ & SPZ-DL4-AA & 35.00 & 2.55 & 30 & 34 & 50 & 70 & 115 & 165 \\
\hline $\begin{array}{c}\text { - Components } \\
\text { - Machines } \\
\text { - Mixed Category }\end{array}$ & $\begin{array}{l}\text { STHP-XLE6- } \\
\text { 2+4-6750mm- } \\
\text { drop-deck }\end{array}$ & 23.38 & 2.65 & 18 & 24 & 35 & 49 & 95 & 180 \\
\hline $\begin{array}{c}\text { - Components } \\
\text { - Machines } \\
\text { - Mixed Category }\end{array}$ & $\begin{array}{c}\text { STZ- } \\
\text { VL4_(SX1+3) }\end{array}$ & 21.13 & 2.75 & 15 & 22 & 34 & 45 & 92 & 165 \\
\hline $\begin{array}{l}\text { - Machinery } \\
\text { - Components }\end{array}$ & $\begin{array}{c}\text { THP- } \\
\text { SL4+4_3m- } \\
\text { drawbar } \\
\text { (oj) }\end{array}$ & 30.74 & 3.00 & 18 & 30 & 38 & 54 & 95 & 165 \\
\hline $\begin{array}{l}\text { - Heavy } \\
\text { Transports } \\
\text { - Components } \\
\text { - Machinery }\end{array}$ & $\begin{array}{l}\text { THP-SL10- } \\
\text { drop-deck }\end{array}$ & 25.74 & 3.00 & 17 & 22 & 34 & 45 & 92 & 175 \\
\hline $\begin{array}{l}\text { - Heavy } \\
\text { Transports } \\
\text { - Components } \\
\text { - Machinery }\end{array}$ & $\begin{array}{l}\text { Goldhofer } \\
\text { STHP/LTV } 10 \\
\text { axles }\end{array}$ & 24.04 & 3.00 & 15 & 20 & 30 & 43 & 93 & 160 \\
\hline $\begin{array}{l}\text { - Heavy } \\
\text { Transports } \\
\text { - Components } \\
\text { - Machinery }\end{array}$ & $\begin{array}{c}\text { THP-SL } \\
\text { long-load } \\
\text { combination }\end{array}$ & 42.52 & 3.00 & 14 & 19 & 30 & 39 & 94 & 160 \\
\hline
\end{tabular}

() angles for calculation up to $180^{\circ}$ are given in the brackets.

Within the performed simulations of newly modelled vehicles for the transports of oversized and excessive cargoes, the data about the width of the relevant swept paths were also recorded. The obtained values represent the required width of the space for ensuring the passage of the set on the road. However, this value does not represent the width of the set, including the cargo. It is also necessary to add the value $b_{0}$ to this width. This is a value that was examined on the basis of the processed statistical data during the passage of an oversized cargo. The relevant $b_{o}$ calculation and more detailed explanations are given in the following section. On the basis of the performed simulations, the detailed Table 3 of the resulting values with the radii of corners, according to the used type of low-loader and the category determined by us, in which the low-loader is included, was determined. 
Table 3. A detailed table of values with the width of the relevant swept path according to the type of the low-loader and category.

\begin{tabular}{|c|c|c|c|c|c|c|c|}
\hline \multirow{3}{*}{ Category } & \multirow{3}{*}{$\begin{array}{l}\text { Type of the Used } \\
\text { Low-Loader }\end{array}$} & \multicolumn{6}{|c|}{ Angle of the Approach of the Vehicle $\left(^{\circ}\right)$} \\
\hline & & $90(90)$ & $105(75)$ & $120(60)$ & $135(45)$ & $150(30)$ & $165(15)$ \\
\hline & & \multicolumn{6}{|c|}{ Width of the Relevant Swept Path (m) } \\
\hline $\begin{array}{l}\text { - Long and Heavy } \\
\text { Transports } \\
\text { - Components }\end{array}$ & $\begin{array}{c}\text { Goldhofer } \\
\text { STHP/LTV } 16 \text { axles }\end{array}$ & 10.20 & 8.90 & 6.80 & 6.10 & 4.40 & 3.80 \\
\hline $\begin{array}{l}\text { - Constructions } \\
\text { - Mixed Category }\end{array}$ & STZ-H10 axles & 15.00 & 14.40 & 11.20 & 9.10 & 6.20 & 4.80 \\
\hline $\begin{array}{l}\text { - Constructions } \\
\text { - Mixed Category }\end{array}$ & SPZ-DL4-AA & 16.90 & 14.60 & 10.70 & 8.80 & 6.10 & 4.30 \\
\hline $\begin{array}{c}\text { - Components } \\
\text { - Machines } \\
\text { - Mixed Category }\end{array}$ & $\begin{array}{l}\text { STHP-XLE6-2+4- } \\
\text { 6750mm-drop-deck }\end{array}$ & 11.20 & 9.60 & 7.30 & 6.30 & 4.40 & 3.70 \\
\hline $\begin{array}{c}\text { - Components } \\
\text { - Machines } \\
\text { - Mixed Category }\end{array}$ & STZ-VL4_(SX1+3) & 9.40 & 8.10 & 6.10 & 5.50 & 3.90 & 3.40 \\
\hline $\begin{array}{l}\text { - Machinery } \\
\text { - Components }\end{array}$ & $\begin{array}{c}\text { THP-SL4+4_3m- } \\
\text { drawbar } \\
(\mathrm{oj})\end{array}$ & 12.50 & 10.60 & 8.10 & 7.00 & 4.70 & 3.90 \\
\hline $\begin{array}{l}\text { - Long and Heavy } \\
\text { Transports } \\
\text { - Components } \\
\text { - Machinery }\end{array}$ & THP-SL10-drop-deck & 9.00 & 7.90 & 6.20 & 5.60 & 4.10 & 3.60 \\
\hline $\begin{array}{l}\text { - Long and Heavy } \\
\text { Transports } \\
\text { - Components } \\
\text { - Machinery }\end{array}$ & $\begin{array}{l}\text { Goldhofer STHP/LTV } \\
10 \text { axles }\end{array}$ & 7.60 & 6.60 & 5.30 & 5.00 & 3.80 & 3.40 \\
\hline $\begin{array}{l}\text { - Long and Heavy } \\
\text { Transports } \\
\text { - Components } \\
\text { - Machinery }\end{array}$ & $\begin{array}{l}\text { THP-SL long-load } \\
\text { combination }\end{array}$ & $\begin{array}{c}7.20 \\
(11.40)\end{array}$ & $6.30(10)$ & $5.60(8.00)$ & $4.70(7.10)$ & $3.70(5.50)$ & $3.40(4.90)$ \\
\hline
\end{tabular}

() in the brackets with the low-loader THP-SL long-load combination, the widths of the swept paths are given, including the structure for securing the cargo.

For a more accurate design and verification of a newly designed or reconstructed intersection, it is recommended to use the newly created vehicles in the relevant program (AutoTURN, easyTRACK, AutoPath) in addition to the tables above.

\section{Determination of the Parameters of the Backbone Roads}

On the basis of the processed statistics, the procedure for determining the resulting values was suggested. This procedure is shown in several tables, whereas the most fundamental results are given in this article. First, it was necessary to determine the number of above-limit transports according to the type of transported cargoes. The tables show the type of the cargo and its number. On the basis of the list of the processed statistical indicators and also the economic point of view, where it is not profitable to determine the route for $100 \%$ of the transported cargoes (if the above-limit transport is realized e.g., once in 3 years), the percentage number of the transports was determined. This is the number of transports for which the route should be suggested ( $90 \%$ and $85 \%)$. For each type of cargo and the observed values (weights, length, width and height of the cargo), the real number of the above-limit transports where the scope of $90 \%$ and $85 \%$ is exceeded was found.

The graphical explanation of the process of determination of the number of the abovelimit transports according to the type of the cargo is shown in Figure 16. 


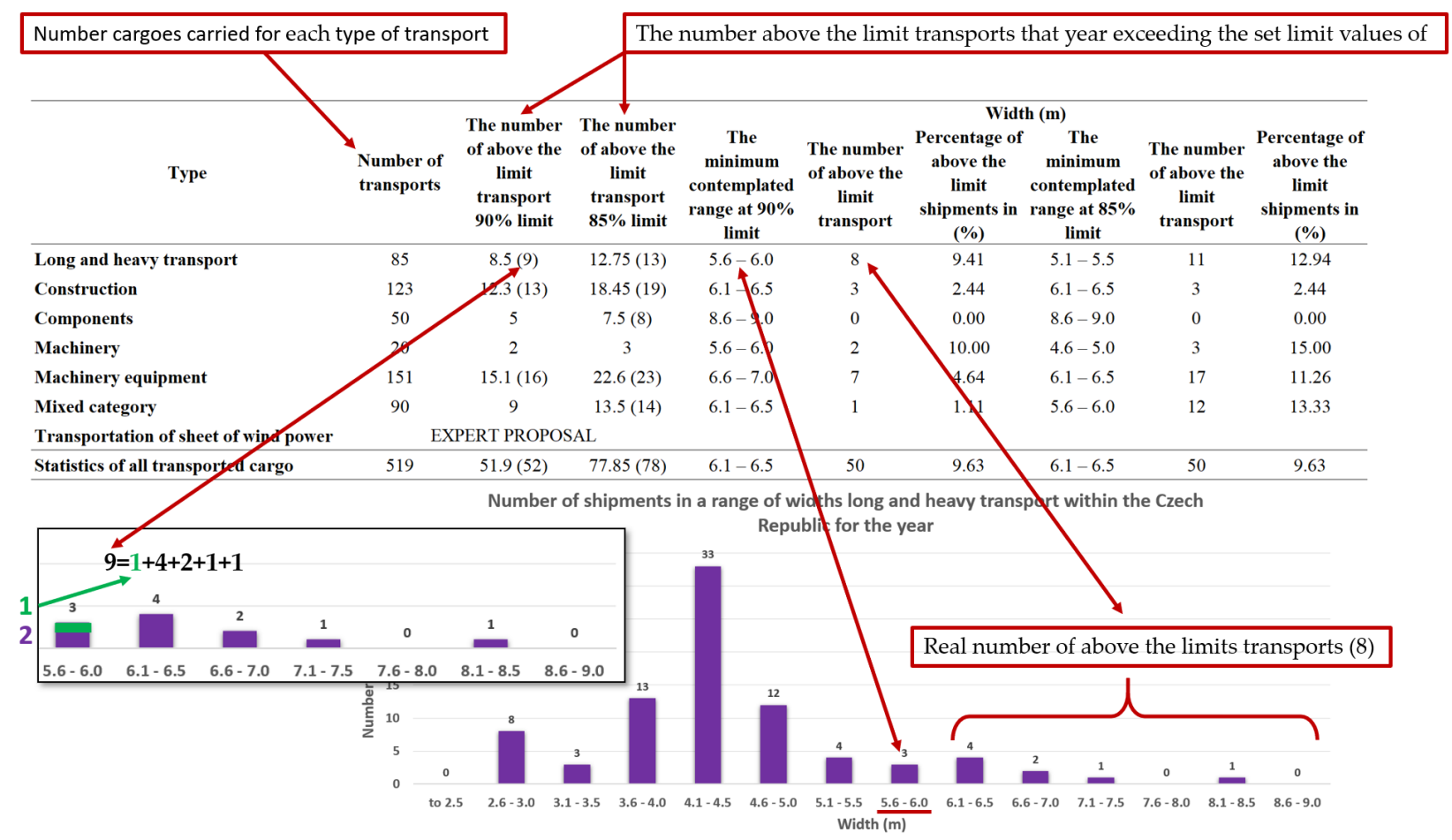

Figure 16. Graphical representation of the procedure to determine the number of the above-limit transports for $90 \%$ number of transports.

The lines in the table with statistics of all transported cargoes are not the average of transport types, but resulting values are calculated separately from the overall statistic of the 519 transports. The statistical sample did not include the transports of wind power plants, the resulting values were determined by professional proposal after consultation with companies involved in the transport of oversized and excessive cargoes.

From the determined number of above-limit transports and the calculated scope in which the transports are, the resulting values were processed. To eliminate possible error in the statistical sample, $5 \%$ allowance was added to the highest range in which $90 \%$ and $85 \%$ of transports belong. This allowance also eliminates the errors in the measurement of the cargo (the sets of oversized or excessive cargoes), but it also includes the allowance for determining the passage space (width, height), tolerance in modelling the swept path during the passage of the set (width, height, length) and load capacity for bridges (weight). This $5 \%$ allowance met all the mentioned criteria.

The resulting tables contain the resulting values for $90 \%$ and $85 \%$ of transports, including the $5 \%$ allowance to which the parameters of the routes for transporting of individual types of cargoes and the parameters for the determination of the backbone routes should be stated. The values for $85 \%$ of transports, including the $5 \%$ allowance, were set as minimum values ( $85 \%$ of transports-minimum requirements for passage). The values for $90 \%$ of transports, including the $5 \%$ allowance, include the routes where local conditions of width, height and weight or other aspects do not limit their suggestion. The table also contains the recommended suggestion-the route for transport of the mentioned types of cargo should meet it. For the suggestion of the backbone routes, the stated values should be kept. The resulting values in Table 4, which are stated in the table, were used for the determination of the passage space. The parameters of the resulting values were further used in the research for modelling the cargoes of oversized and excessive sets of vehicles for verification of the swept paths in the space of the crossroads.

Similarly, as the determination of the final values of widths and heights for the transport of excessive and oversized cargoes, the table of the final values of weights and lengths of sets were determined (see Table 5). The aspect of the recommended suggestion from the perspective of loading capacity of bridges on backbone routes is very important here. 
Table 4. Table of resulting values of width and height for the transport of oversized cargoes.

\begin{tabular}{|c|c|c|c|c|c|c|c|c|c|}
\hline Type & $\begin{array}{l}\text { Number of } \\
\text { Transports }\end{array}$ & $\begin{array}{l}\text { The Number of } \\
\text { above the Limit } \\
\text { Transport } 90 \%\end{array}$ & $\begin{array}{l}\text { The Number of } \\
\text { above the Limit } \\
\text { Transport } 85 \%\end{array}$ & $\begin{array}{c}90 \% \text { Transports + } \\
5 \% \text { to Width }\end{array}$ & $\begin{array}{c}\text { Width }(\mathrm{m}) \\
85 \% \text { Transports }+ \\
5 \% \text { to Width }\end{array}$ & $\begin{array}{c}\text { Recommended } \\
\text { Proposal }\end{array}$ & $\begin{array}{c}90 \% \text { Transports + } \\
5 \% \text { to Height }\end{array}$ & $\begin{array}{c}\text { Height }(\mathrm{m}) \\
85 \% \text { Transports }+ \\
5 \% \text { to Height }\end{array}$ & $\begin{array}{l}\text { Recommended } \\
\text { Proposal }\end{array}$ \\
\hline \multirow{5}{*}{$\begin{array}{l}\text { Long and heavy } \\
\text { transport } \\
\text { Construction } \\
\text { Components } \\
\text { Machinery } \\
\text { Machinery } \\
\text { equipment } \\
\text { Mixed category } \\
\text { Transportation of } \\
\text { sheet of wind } \\
\text { power }\end{array}$} & 85 & $8.5(9)$ & $12.75(13)$ & 6.3 & 5.775 & 6.30 & 5.775 & 5.775 & 5.80 \\
\hline & $\begin{array}{l}123 \\
50 \\
20\end{array}$ & $\begin{array}{c}12.3(13) \\
5 \\
2\end{array}$ & $\begin{array}{c}18.45(19) \\
7.5(8) \\
3\end{array}$ & $\begin{array}{c}6.825 \\
9.45 \\
6.3\end{array}$ & $\begin{array}{l}6.825 \\
9.45 \\
5.25\end{array}$ & $\begin{array}{l}6.90 \\
9.50 \\
6.30\end{array}$ & $\begin{array}{c}4.725 \\
6.3 \\
4.725\end{array}$ & $\begin{array}{l}4.725 \\
5.775 \\
4.725\end{array}$ & $\begin{array}{l}4.80 \\
6.30 \\
4.80\end{array}$ \\
\hline & 151 & $15.1(16)$ & $22.6(23)$ & 7.35 & 6.825 & 7.40 & 6.3 & 5.775 & 6.30 \\
\hline & 90 & 9 & $13.5(14)$ & 6.825 & 6.3 & 6.90 & 4.725 & 4.725 & 4.80 \\
\hline & & EXPERT PROPOSAL & & 3.5 & 3.5 & 3.50 & 4.8 & 4.8 & 4.80 \\
\hline $\begin{array}{l}\text { Statistics of all } \\
\text { transported cargo }\end{array}$ & 519 & $51.9(2)$ & $77.85(78)$ & 6.825 & 6.825 & 6.90 & 5.775 & 5.775 & 5.80 \\
\hline $\begin{array}{l}\text { BACKBONE } \\
\text { ROUTE-DRAFT }\end{array}$ & & & & & & 9.50 & & & 6.30 \\
\hline
\end{tabular}

Table 5. Resulting values of weight and length for transport of oversized cargoes.

\begin{tabular}{|c|c|c|c|c|c|c|c|c|c|}
\hline Type & $\begin{array}{l}\text { Number of } \\
\text { Transports }\end{array}$ & $\begin{array}{l}\text { The Number of } \\
\text { above the Limit } \\
\text { Transport } 90 \%\end{array}$ & $\begin{array}{l}\text { The Number of } \\
\text { above the Limit } \\
\text { Transport } 85 \%\end{array}$ & $\begin{array}{l}90 \% \text { Transports + } \\
5 \% \text { to Weights }\end{array}$ & $\begin{array}{c}\text { Weights }(\mathrm{m}) \\
\text { 85\% Transports + } \\
5 \% \text { to Weights }\end{array}$ & $\begin{array}{l}\text { Recommended } \\
\text { Proposal }\end{array}$ & $\begin{array}{l}90 \% \text { Transports + } \\
5 \% \text { to Length }\end{array}$ & $\begin{array}{c}\text { Length }(\mathrm{m}) \\
85 \% \text { Transports }+ \\
5 \% \text { to Length }\end{array}$ & $\begin{array}{c}\text { Recommended } \\
\text { Proposal }\end{array}$ \\
\hline \multirow{5}{*}{$\begin{array}{l}\text { Long and heavy } \\
\text { transport } \\
\text { Construction } \\
\text { Components } \\
\text { Machinery } \\
\text { Machinery } \\
\text { equipment } \\
\text { Mixed category } \\
\text { Transportation of } \\
\text { sheet of wind } \\
\text { power }\end{array}$} & 85 & $8.5(9)$ & $12.75(13)$ & 357 & 315 & 360 & 52.5 & 52.5 & 53.00 \\
\hline & $\begin{array}{l}123 \\
50 \\
20\end{array}$ & $\begin{array}{c}12.3(13) \\
5 \\
2\end{array}$ & $\begin{array}{c}18.45(19) \\
7.5(8) \\
3\end{array}$ & $\begin{array}{l}105 \\
273 \\
84\end{array}$ & $\begin{array}{l}105 \\
273 \\
84\end{array}$ & $\begin{array}{l}110 \\
275 \\
85\end{array}$ & $\begin{array}{r}31.5 \\
47.25 \\
26.25\end{array}$ & $\begin{array}{l}28.35 \\
47.25 \\
26.25\end{array}$ & $\begin{array}{l}32.00 \\
48.00 \\
27.00\end{array}$ \\
\hline & 151 & $15.1(16)$ & $22.6(23)$ & 273 & 231 & 275 & 47.25 & 42 & 48.00 \\
\hline & 90 & 9 & $13.5(14)$ & 63 & 42 & 63 & 23.1 & 23.1 & 23.50 \\
\hline & & EXPERT PROPOSAL & & 40 & 40 & 40 & 55 & 55 & 55.00 \\
\hline $\begin{array}{l}\text { Statistics of all } \\
\text { transported cargo }\end{array}$ & 519 & $51.9(2)$ & $77.85(78)$ & 273 & 273 & 275 & 47.25 & 42 & 48.00 \\
\hline $\begin{array}{l}\text { BACKBONE } \\
\text { ROUTE-DRAFT }\end{array}$ & & & & & & 360 & & & 55 \\
\hline
\end{tabular}




\section{The Clearance Gauge and the Distance from the Solid Obstacles}

The clearance gauge and the distance from the solid obstacles were determined on the basis of the processed statistics. The scheme of the clearance gauge is obvious from Figure 17. For the calculated clearance gauge, similar requirements are valid as for the clearance gauge in ČSN 736201 Design of Bridges [46].

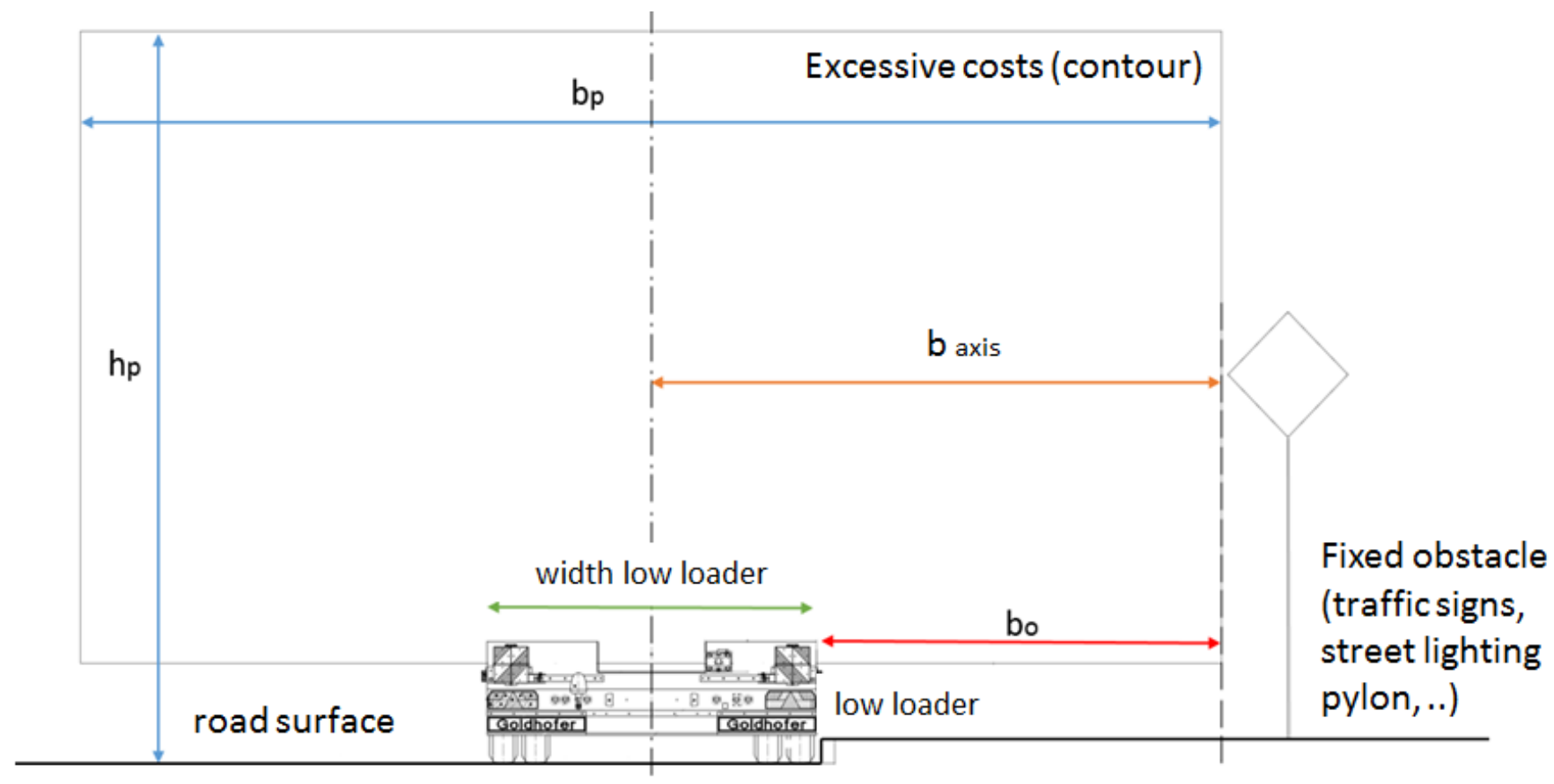

Figure 17. A scheme of the clearance gauge including the distance from the solid obstacle.

The width of the clearance gauge $b p$ for the passage of the oversized cargoes is stated in Table 6. In the table, also stated is the distance from the axis of the low-loader to the edge of the outline of the oversized cargo $b$ axis ( $b p / 2$ - rounded). The distance depending on the passage of $90 \%$ transports (optimal value), passage of $85 \%$ transports (minimum values) and recommended distance were determined for individual types of cargoes.

The distance from the solid obstacle $b_{o}$ (traffic signs, public lighting, railing, greenery, crash barriers, etc.) is stated in Table 7. This distance depends on the type of the transport and the smallest width of the low-loader on which the oversized cargo is transported. For individual types of cargoes, the distances are stated depending on the passage of $90 \%$ transports (optimum values), passage of $85 \%$ transport (minimum values) and recommended distances. The values stated in the table should be kept on the backbone routes. The smallest width of the used low-loader was determined on the basis of the type of the cargo and division of these vehicles into categories. 
Table 6. The width of the clearance gauge including the distance from the axis to the edge of the outline of the cargo.

\begin{tabular}{|c|c|c|c|c|c|c|c|}
\hline \multirow[b]{2}{*}{ Type } & \multirow{2}{*}{$\begin{array}{c}\text { The Min. } \\
\text { Width Used } \\
\text { Low Loader } \\
\text { [m] }\end{array}$} & \multicolumn{3}{|c|}{ Width $b p(\mathrm{~m})$} & \multicolumn{3}{|c|}{$b$ axis $(\mathrm{m})$} \\
\hline & & $\begin{array}{l}\text { Optimal for } \\
90 \% \text { of } \\
\text { Transports }\end{array}$ & $\begin{array}{c}\text { Optimal for } \\
85 \% \text { of } \\
\text { Transports }\end{array}$ & $\begin{array}{l}\text { Recommended } \\
\text { Proposal }\end{array}$ & $\begin{array}{l}\text { Optimal- } \\
\text { Rounded } \\
\text { to }\end{array}$ & $\begin{array}{l}\text { Min. } \\
\text { Rounded to }\end{array}$ & Recommended \\
\hline $\begin{array}{l}\text { Long and } \\
\text { heavy } \\
\text { transport }\end{array}$ & 3.00 & 6.30 & 5.775 & 6.30 & 3.15 & 2.90 & 3.15 \\
\hline Construction & 2.55 & 6.825 & 6.825 & 6.90 & 3.45 & 3.45 & 3.45 \\
\hline Components & 2.55 & 9.45 & 9.45 & 9.50 & 4.75 & 4.75 & 4.75 \\
\hline Machinery & 2.55 & 6.30 & 5.25 & 6.30 & 3.15 & 2.65 & 3.15 \\
\hline $\begin{array}{l}\text { Machinery } \\
\text { equipment }\end{array}$ & 2.75 & 7.35 & 6.825 & 7.35 & 3.70 & 3.45 & 3.70 \\
\hline Mixed category & 2.55 & 6.825 & 6.30 & 6.90 & 3.45 & 3.15 & 3.45 \\
\hline $\begin{array}{l}\text { Transportation } \\
\text { of sheet of } \\
\text { wind power }\end{array}$ & 2.52 & 3.50 & 3.50 & 3.50 & 1.75 & 1.75 & 1.75 \\
\hline $\begin{array}{l}\text { Statistics of all } \\
\text { transported } \\
\text { cargo }\end{array}$ & 2.52 & 6.825 & 6.825 & 6.90 & 3.45 & 3.45 & 3.45 \\
\hline $\begin{array}{c}\text { BACKBONE } \\
\text { ROUTE- } \\
\text { DRAFT }\end{array}$ & 2.52 & & 9.50 & & & 4.75 & \\
\hline
\end{tabular}

The statistics of all transported cargoes is not an average from the types of transport, but the resulting values are evaluated separately from the overall statistics of 519 transports.

Table 7. The distance from the solid obstacle and the clearance gauge.

\begin{tabular}{|c|c|c|c|c|c|c|c|}
\hline \multirow[b]{2}{*}{ Type } & \multirow{2}{*}{$\begin{array}{l}\text { The Min. } \\
\text { Width Used } \\
\text { Low-Loader } \\
\text { (m) }\end{array}$} & \multicolumn{3}{|c|}{$b_{o}(\mathrm{~m})$} & \multicolumn{3}{|c|}{ Height $h p(\mathrm{~m})$} \\
\hline & & $\begin{array}{l}\text { Optimal } \\
\text { Rounded to }\end{array}$ & $\begin{array}{l}\text { Minimal } \\
\text { Rounded to }\end{array}$ & Recommended & $\begin{array}{l}\text { Optimal- } \\
\text { for } 90 \% \text { of } \\
\text { Transports }\end{array}$ & $\begin{array}{l}\text { Min.- } 85 \% \\
\text { of transports }\end{array}$ & $\begin{array}{l}\text { Recommended } \\
\text { Proposal }\end{array}$ \\
\hline $\begin{array}{l}\text { Long and } \\
\text { heavy } \\
\text { transport }\end{array}$ & 3.00 & 1.65 & 1.40 & 1.65 & 5.775 & 5.775 & 5.80 \\
\hline Construction & 2.55 & 2.20 & 2.20 & 2.20 & 4.725 & 4.725 & 4.80 \\
\hline Components & 2.55 & 3.50 & 3.50 & 3.50 & 6.3 & 5.775 & 6.30 \\
\hline Machinery & 2.55 & 1.90 & 1.40 & 1.90 & 4.725 & 4.725 & 4.80 \\
\hline $\begin{array}{l}\text { Machinery } \\
\text { equipment }\end{array}$ & 2.75 & 2.35 & 2.10 & 2.35 & 6.3 & 5.775 & 6.30 \\
\hline Mixed category & 2.55 & 2.20 & 1.90 & 2.20 & 4.725 & 4.725 & 4.80 \\
\hline $\begin{array}{l}\text { Transportation } \\
\text { of sheet of } \\
\text { wind power }\end{array}$ & 2.52 & 0.50 & 0.50 & 0.50 & 4.8 & 4.8 & 4.80 \\
\hline $\begin{array}{l}\text { Statistics of all } \\
\text { transported } \\
\text { cargo }\end{array}$ & 2.52 & 2.20 & 2.20 & 2.20 & 5.775 & 5.775 & 5.80 \\
\hline $\begin{array}{c}\text { BACKBONE } \\
\text { ROUTE- } \\
\text { DRAFT }\end{array}$ & 2.52 & & 3.50 & & & 6.30 & \\
\hline
\end{tabular}

The statistics of all transported cargoes are not averages from the types of transport, but the resulting values are evaluated separately from the overall statistics of 519 transports. 
The value of $b_{o}$ was calculated as:

$$
b_{o}=b_{\text {axis }}-\left(\frac{x}{2}\right)
$$

where:

- $\quad b_{o}$ is the distance from the solid obstacle;

- $b_{\text {axis }}$ is the distance from the axis of the low-loader to the edge of the outline of the oversized cargo;

- $\quad x$ is the the smallest width of the used low-loader.

The height of the clearance gauge $h p$ is stated in Table 7. This height was determined on the basis of processed statistics of the transports. For individual types of cargoes, the height is determined with respect to the passage of $90 \%$ transport (optimum values), passage of $85 \%$ transport (minimum values) and the recommended height. The values stated in the table should be kept on the backbone routes. The height of the clearance gauge is the basis for the free height of the passage, which is stated in article 6.3.2. of ČSN 736201 Design of Bridges [46].

\section{Discussions}

However, the above-mentioned outputs may not only serve for design practices in the Czech Republic but also as a technical basis for neighbouring countries. Statistical data of transported cargoes are not only from transports that took place within the state but also from transports in transit, or transports where the source/destination was in the Czech Republic and the product was transported through other surrounding countries.

Using the created models of oversized sets and created technical parameters of radii (corners of intersections, determination of island types, modifications of the approach, determination of clearance gauge and distances from solid obstacles), the current unsatisfying situation would improve, which complicates the transport of excessive loads on their frequent routes and thus also affects the competitiveness of companies that produce products of non-standard dimensions. In general, transport infrastructure is a system in which one negative element (e.g., an improperly designed roundabout) can fundamentally affect the behaviour of transport and its sustainability. In particular, it has an impact on transport safety, public health and the environment.

\section{Conclusions}

The present article deals with many years of research into the issue of transport of excessive and oversized cargoes from the point of view of determining the parameters of roads with an emphasis on safe and sustainable transport infrastructure [53]. To understand the issue itself, it is necessary to know all the issues of transport of excessive cargo from the perspective of the carrier, designer, administrator of the transport infrastructure, etc. As this issue was unsolved and largely neglected, the authors of the article have been conducting research since 2011 on roads both in the Czech Republic and abroad (Slovakia, Poland, Germany, Austria, Slovenia, Hungary, Ukraine). The aim of the research was system analysis and statistical evaluation of transports of excessive and oversized cargoes, subsequent creation of vehicle models that transport these cargoes and, last but not least, the determination of technical parameters for the passage of excessive and oversized transports within the transport infrastructure. It was a matter of determining the values of the parameters of the radii of the corners of intersections (crossroads and roundabouts), widths and heights for the transport of cargoes (e.g., headroom under bridges) and the determination of distance from solid obstacles. The main idea is to create a functioning, efficient and especially safe infrastructure both within cities and outside of them, to ensure the passage of excessive and oversized transports and to verify critical points of the route.

Many recording devices were used in the research (cameras, video cameras, $360^{\circ}$ cameras, cameras mounted on a floating vehicle, etc.). Furthermore, laser scanning was used for accurate surveying and subsequent verification of critical points on the route. For 
the purposes of vehicle modelling, measurements of vehicles transporting excessive and oversized cargoes were performed using GPS technology with a subsequent control of unmanned aerial vehicles (drones). Special programs for processing data, GOODVISION and DATA FROM SKY, were used for data processing, especially data from cameras (recording devices, drones). Software programs were used to evaluate measurements using GPS and for software verification of swept paths. For the evaluation itself, own data processing procedures were designed and simulations of vehicle passage and probabilistic analyses were performed in terms of passage through critical points of the route (e.g., a roundabout).

On the basis of the processed data and evaluated results, we can verify the current state of the transport infrastructure, but especially verify the critical points on the route of excessive or oversized cargo. At these critical points, we will determine whether the area is properly designed or whether it is necessary to proceed with its modification. The precondition for the above-mentioned outputs is the practical use of results in planning the transport infrastructure on the entire communication network and the possibility of its application for designing activities associated with construction or reconstruction of intersections on routes of frequent transport of excessive and oversized cargoes. The outputs of the work now serve as a basis for the processing of technical conditions, which will include procedures and technical recommendations within the design practice in the Czech Republic.

Figure 18 shows an example of the possibility of using our technical recommendations and using the modelled vehicle to verify the swept paths in the transport of oversized cargo. Modifications of the roundabout are proposed here, which suggests the possibility of an excessive set to pass through the roundabout in the opposite direction of travel. This is a situation where it is more appropriate to modify the roundabout in the opposite direction due to its geometric layout. The following modifications are proposed at the roundabout:

- Increasing the rigidity of the structure of the dividing islands for the passage of the set on the main road;

- The existing corner of the roundabout is only modified according to the new design of the structure, the existing geometry of the corner complied;

- The truck apron is modified, including the use of the raised part of the ring for the passage of excessive and oversized cargoes (the modified part of the ring was designed only in the opposite direction, the remaining part was the original);

- Relocation of the location of the pole of the traffic sign on the central island to the prescribed distance of $b_{o}$ to ensure the passage;

- The posts on the dividing islands are attached with the help of a rotating special socket, which allows easy disassembly (this modification is also used on the dividing islands);

- It is also proposed to move the location of pole of the pedestrian crossing to the required safe distance (a longer beam was used on the pole);

- The required height of the clearance gauge $h p$ is also ensured. 


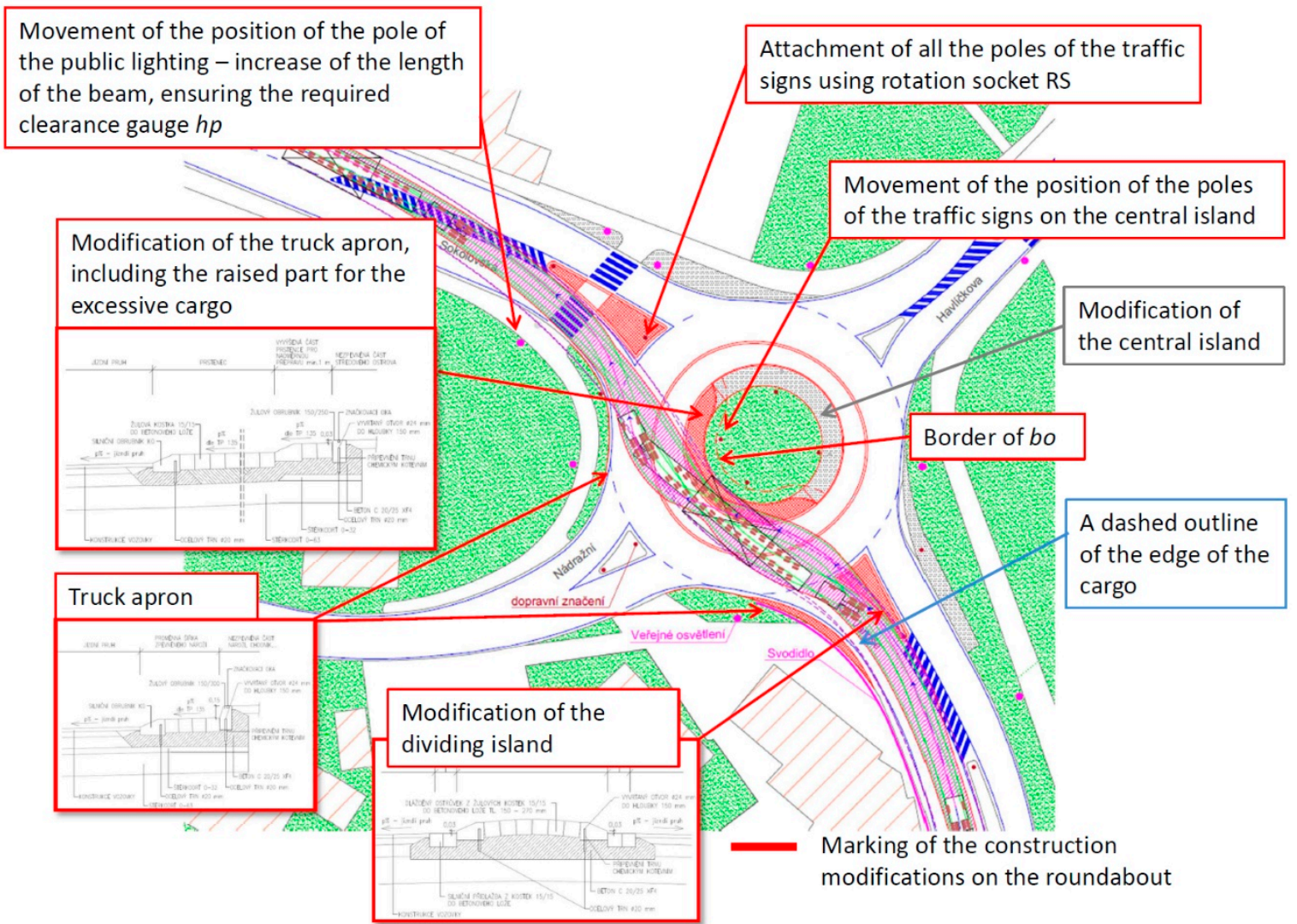

Figure 18. An example of the modification of an existing roundabout for the passage of oversized cargo in the opposite direction.

Author Contributions: Conceptualization, J.P. and V.K.; methodology, J.P.; analysis, J.P. and V.K.; writing - original draft preparation, J.P.; writing - review and editing, V.K.; project administration, J.P. and V.K. All authors have read and agreed to the published version of the manuscript.

Funding: This research was funded by VŠB-TUO by the Ministry of Education, Youth, and Sports of the Czech Republic.

Institutional Review Board Statement: Not applicable.

Informed Consent Statement: Not applicable.

Data Availability Statement: Data is contained within the article.

Acknowledgments: The work was supported by the conceptual development of science, research, and innovation assigned to VŠB-TUO by the Ministry of Education, Youth and Sports of the Czech Republic.

Conflicts of Interest: The authors declare no conflict of interest.

\section{References}

1. European Best Practice Guidelines for Abnormal Road Transports. European Commission Directorate-General for Energy and Transport. 2006. Available online: http:/ / ec.europa.eu/transport/road_safety/vehicles/doc/abnormal_transport_guidelines_ en.pdf (accessed on 30 January 2021).

2. Petraska, A.; Jarasuniene, A.; Ciziuniene, K. Routing Methodology for Heavy-weight and Oversized Loads Carried by Rail Transpor. Procedia Eng. 2017, 178, 589-596. [CrossRef]

3. Melnyk, O.; Malaksiano, M. Effectiveness assessment of non-specialized vessel acquisition and operation projects, considering their suitability for oversized cargo Transportation. Trans. Marit. Sci. 2020, 9, 23-34. [CrossRef]

4. David, A.; Madudova, E. The Danube river and its importance on the Danube countries in cargo transport. Transp. Res. Procedia 2019, 40, 1010-1016. [CrossRef]

5. Neal, C.; Koo, T.T. Demand for cargo airships: An analysis of mode choice decision making in the freight transport industry. J. Air Transp. Manag. 2020, 83, 101741. [CrossRef] 
6. Zolin, A.; Didkovsky, A. Development of the transport airship for cargo delivery to the Vostochnz Cosmodrome. AIP Conf. Proc. 2019, 2171, 120004. [CrossRef]

7. Funk, C.; Shraddhanand, S. Chapter 2-Drought early warning-Definitions, challenges, and opportunities. In Drought Early Warning and Forecasting, Theroy and Practice; Elsevier: Amsterdam, The Netherlands, 2020; pp. 23-42. [CrossRef]

8. Quiring, S. Hydrology, Floods and Droughts/Drought. In Encyclopedia of Atmospheric Sciences, 2nd ed.; Elsevier: Amsterdam, The Netherlands, 2015; pp. 193-200. [CrossRef]

9. Paulauskas, V.; Paulauskas, D.; Placiene, B.; Jonkus, M.; Kaulitsky, A. Inland waterway shipping of oversized cargo. In Proceedings of the International Conference Transport Means, Juodkrante, Lithuania, 20-22 September 2017; pp. 819-823.

10. Lytvynenko, S.L. Economic and organizational grounds for usage of handling equipment at air freight of extra heavy and oversized cargos. Actual Probl. Econ. 2012, 132, 150-158.

11. Petru, J. The Passage of Excessive and Oversize Transport in the Area of Intersections. Ph.D. Thesis, VSB-Technical University of Ostrava, Ostrava, Czech Republic, 2014.

12. Petru, J.; Krivda, V. The Process of Setting the Parameters for Ensuring Passage of Oversized Cargos. Balt. J. Road Bridg. Eng. 2019, 14, 425-442. [CrossRef]

13. NOSRETI a.s. Available online: http://www.nosreti-doprava.cz/doprava-nosreti.html (accessed on 3 April 2014 ).

14. Gonzalo-Orden, H.; Rajo, M.; Perez-Acebo, H.; Linares, A. Traffic Calming Measures and their Effect on the Variation of Speed. Transp. Res. Procedia 2016, 18, 349-356. [CrossRef]

15. Lee, G.; Joo, S.; Oh, C.; Choi, K. An evaluation framework for traffic calming measures in residential areas. Transp. Res. Part D Transp. Environ. 2013, 25, 68-76. [CrossRef]

16. Macioszek, E. Oversize cargo transport in road transport-Problems and issues. Sci. J. Silesian Univ. Technol. Ser. Transp. 2020, 108, 133-140. [CrossRef]

17. Tollazzi, T.; Mauro, R.; Guerrieri, M.; Rejcelj, M. Comparative Analysis of Four New Alternative Types of Roundabouts: “Turbo", "Flower", "Target" and "Four-Flyover" Roundabout. Period. Polytech. Civ. Eng. 2016, 6, 51-60. [CrossRef]

18. Guerrieri, M.; Mauro, R.; Tollazzi, T. Turbo-Roundabout: Case Study of Driver Behaviour and Kinematic Parameters of Light and Heavy Vehicles. J. Transp. Eng. Part A Syst. 2019, 145, 05019002. [CrossRef]

19. Kacovsky, J.; Kocourek, J.; Padelek, T. Examination of Logical Trends in Traffic and Traffic Accidents in the Context of Road Safety at Roundabouts. In Proceedings of the Smart Cities Symposium, Prague, Czech Republic, 23-24 May 2019.

20. Petru, J.; Krivda, V. An Analysis of Turbo Roundabouts from the Perspective of Sustainability of Road Transportation. Sustainability 2021, 13, 2119. [CrossRef]

21. Skvain, V.; Petru, J.; Krivda, V. Turbo-Roundabouts and their Basic Evaluation at Realized Constructions in Czech Republic. Procedia Engineering. In Proceedings of the 3rd International Conference on Structural and Physical Aspects of Construction Engineering (SPACE 2016), Bratislava, Slovakia, 3-4 October 2017; pp. 283-290.

22. Saplioglu, M.; Adin, M.M. Choosing safe and suitable bicycle routes to integrate cycling and public transport systems. J. Transp. Health 2018, 10, 236-252. [CrossRef]

23. Tzvetkova, S.D. Development of Bicycle Transport in the City of Sofia as Part of the Concept for Stable Urban Mobility. In Proceedings of the 2018 9th International Conference on Environmental Science and Technolog, Prague, Czech Republic, 20-22 June 2018. [CrossRef]

24. Yang, H.; Cheng, Z.; Cheng, G.; Wang, L.; Ruan, Z.Y.; Zheng, Y.J. The impact of a public bicycle-sharing system on urban public transport networks. Transp. Res. Part A Policy Pract. 2018, 107, 246-256. [CrossRef]

25. Hanna, S. Erikoiskuljetustoiminta Tienpitäjän Näkökulmasta. Tiehallinnon Selvityksiä. Available online: http://www.elykeskus. fi/fi/Liikenne/Lupaasiat/Erikoiskuljetukset/Tilastot/Documents/Erikoiskuljetukset_tienpitajan_nakokulmasta.pdf (accessed on 24 December 2017).

26. Nyrhinen, E.; Gröndahl, S. Vaasan Tiepiirin Alueen Kiertoliittymät, ISSN 1457-991X. Available online: http:/ /alk.tiehallinto.fi/ julkaisut/pdf/4000477-vvaasan_tiep_kiertoliitt.pdf (accessed on 24 December 2017).

27. Laitinen, K. Paateid Kehitt ja Suurt Erikoiskulj, ISSN 1459-1561. Available online: http://alk.tiehallinto.fi/julkaisut/pdf2/40006 63-v-paateid_kehitt_ja_suurt_erikoiskulj.pdf (accessed on 24 December 2017).

28. Etelä, ja Keski-Pohjanmaan Tuulivoima ja Erikoiskuljetukset. Available online: http://www.epliitto.fi/upload/files/EP_ja_KP_ tuulivoima_ja_erikoiskuljetukset_21102013.pdf (accessed on 24 December 2018).

29. Sustainable Safe Road Design a Practical Manual DHV Environment and Transportatio. Available online: https://www.mnt.ee/ sites/default/files/content-editors /Failid/Juhendid/ehitus/safe_road_design_manual_final.pdf (accessed on 20 January 2019).

30. Handbuch für die Bemessung von Straßenverkehrsanlagen (HBS); FGSV Verlag: Köln, Germany, 2005; ISBN 3-937356-44-4.

31. Highway Capacity Manual (HCM); Transportation Research Board, National Research Council: Washington, DC, USA, 2000; ISBN 0-309-06681-6.

32. Young Researcher. Available online: http://mladivyzkumnici.cz/cz/section/detail/1?section_id=6 (accessed on 24 December 2017).

33. Petru, J.; Krivda, V. Height and Width Parameters for Ensuring Passage of Excessive Loads on Roads. Acta Polytech. 2017, 57, 209-217. [CrossRef]

34. Kocarkova, D. Traffic Conflict Techniques in Czech Republic. Procedia Soc. Behav. Sci. 2012, 53, 1029-1034. [CrossRef] 
35. Kocourek, J.; Padelek, T. Application of the Traffic Conflict Technique in the Czech Republic. In Proceedings of the Smart Cities Symposium, Prague, Czech Republic, 26-27 May 2016.

36. Krivda, V.; Petru, J.; Macha, D.; Plocova, K.; Fibich, D. An Analysis of Traffic Conflicts as a Tool for Sustainable Road Transport. Sustainability 2020, 12, 7198. [CrossRef]

37. Kiec, M.; Ambros, J.; Bak, R.; Gogolin, O. Evaluation of safety effect of turbo-roundabout lane dividers using floating car data and video observation. Accid. Anal. Prev. 2019, 8, 302-310. [CrossRef]

38. Hanzl, J. Transport of oversized cargo in the Czech Republic-Critical places on the route from the perspective of road infrastructure and traffic safety. In Proceedings of the International Conference of 23rd International Scientific Conference on Transport Means, Palanga, Lithuania, 2-4 October 2019; pp. 615-620.

39. GoodVision. Available online: https:/ / goodvisionlive.com (accessed on 20 September 2020).

40. Data from Sky. Available online: https:/ / datafromsky.com (accessed on 20 September 2020).

41. Bassani, M.; Mussone, L. Experimental analysis of operational data for roundabouts through advanced image processing. J. Traffic Transp. Eng. 2020, 7, 482-497. [CrossRef]

42. Godavarthy, P.R.; Russell, E.; Landman, D. Using vehicle simulations to understand strategies for accommodating oversize, overweight vehicles at roundabouts. Transp. Res. Part A Policy Pract. 2016, 87, 41-50. [CrossRef]

43. On the Approval of Technical Competence and on Technical Conditions for the Operation of Vehicles on Roads; Decree No. $341 / 2002$ Coll; Ministry of Transport and Communications: Prague, Czech Republic, 2002.

44. Eurocode 1: Actions on Structures-Part 2: Actions on Bridges by Traffic; CSN EN 1991-2; Czech Standards Institute: Prague, Czech Republic, 2005.

45. Load Capacity of Road Bridges; CSN 73 6222; Office for Technical Standardization, Metrology and State Testing: Prague, Czech Republic, 2009.

46. Design of Bridge Structures; CSN 73 6201; Czech Standards Institute: Prague, Czech Republic, 2008.

47. Brezina, S.; Dragcevic, V.; Stanceric, I. Approach Alignment Impact on the Geometric Design of Urban Roundabout. Transp. Res. Procedia 2020, 45, 700-707. [CrossRef]

48. Krivda, V.; Petru, J. Usage of Video Analysis of Traffic Conflicts for the Evaluation of Inappropriately Designed Building Elements on Intersections. In Proceedings of the IOP Conference Series: Earth and Environmental Science on 2nd International Conference on Sustainable Development in Civil, Urban and Transportation Engineering (CUTE), Banda Aceh, Indonesia, 26-27 September 2018. [CrossRef]

49. Luo, Y.; Zhang, Y.; Huang, J.; Yang, H. Multi-route planning of multimodal transportation for oversize and heavyweight cargo based on reconstruction. Comput. Oper. Res. 2021, 128, 105172. [CrossRef]

50. CleveRa. Available online: www.clevera.cz (accessed on 5 August 2020).

51. BMS. Available online: www.bms.clevera.cz (accessed on 5 August 2020).

52. Petru, J.; Dolezel, J.; Krivda, V. Assessment of the transport routes of oversized and excessive loads in relation to the passage through roundabout. IOP Conf. Ser. Mater. Sci. Eng. 2017, 236, 12033. [CrossRef]

53. Makarova, I.; Pashkevich, A.; Shubenkova, K. Safe Routes as One of the Ways to Reduce the Number of Road Accidents Victims. In Lecture Notes in Networks and Systems; Springer International Publishing AG: Basel, Switzerland, 2018; Volume 21, pp. 73-84. 